\title{
FOXL2: a central transcription factor of the ovary
}

\author{
Adrien Georges ${ }^{1,2}$, Aurelie Auguste ${ }^{1,2}$, Laurianne Bessière ${ }^{1,2}$, Anne Vanet ${ }^{1,2}$, \\ Anne-Laure Todeschini ${ }^{1,2}$ and Reiner A Veitia ${ }^{1,2}$ \\ ${ }^{1}$ CNRS UMR 7592, Institut Jacques Monod, 15 Rue Hélène Brion, 75013 Paris, France \\ ${ }^{2}$ Université Paris Diderot, Paris VII, Paris, France
}

Correspondence should be addressed to R A Veitia Email

veitia.reiner@ijm.univ-parisdiderot.fr

\begin{abstract}
Forkhead box L2 (FOXL2) is a gene encoding a forkhead transcription factor preferentially expressed in the ovary, the eyelids and the pituitary gland. Its germline mutations are responsible for the blepharophimosis ptosis epicanthus inversus syndrome, which includes eyelid and mild craniofacial defects associated with primary ovarian insufficiency. Recent studies have shown the involvement of FOXL2 in virtually all stages of ovarian development and function, as well as in granulosa cell (GC)-related pathologies. A central role of FOXL2 is the lifetime maintenance of GC identity through the repression of testis-specific genes. Recently, a highly recurrent somatic FOXL2 mutation leading to the p.C134W subtitution has been linked to the development of GC tumours in the adult, which account for up to $5 \%$ of ovarian malignancies. In this review, we summarise data on FOXL2 modulators, targets, partners and post-translational modifications. Despite the progresses made thus far, a better understanding of the impact of FOXL2 mutations and of the molecular aspects of its function is required to rationalise its implication in various pathophysiological processes.
\end{abstract}

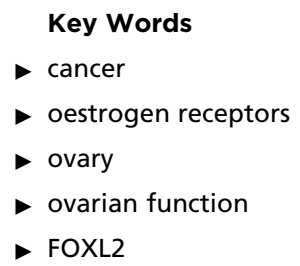

Journal of Molecular Endocrinology (2014) 52, R17-R33

\section{Introduction}

The mammalian ovary is a complex organ, ensuring various functions essential to the reproductive process. Its most obvious role is the production and release of functional female gametes, the oocytes. In addition, the ovary also has a critical endocrine function, including notably the production of oestrogens, which are essential to the development of female genitalia, and progesterone, which is necessary for the establishment of pregnancy. These functions are tightly coordinated throughout folliculogenesis, a dynamic process involving a continuous differentiation of three cell types: the oocyte and the surrounding granulosa and theca cells. A simplified summary of this process is outlined in Fig. 1.

The coordinated differentiation of the oocyte and the surrounding somatic cells is under the control of a large number of signaling factors including gonadotropins (follicle-stimulating hormone (FSH) and luteinizing hormone (LH)), members of the transforming growth factor $\beta$ (TGF $\beta$ ) family (GDF-9, BMP15, BMP4, BMP7, AMH, FST, etc.), growth factors (IGF1, FGF2, KITL, etc.) and sex hormones (estradiol, testosterone, progesterone, etc.), which mediate cellular and tissue-level communication (Edson et al. 2010). Granulosa cells (GCs) play a central role in the coordination of folliculogenesis through their direct communication with the oocyte and theca cells, their sensitivity to pituitary hormones and their ability to produce oestrogens, anti-Müllerian hormone (AMH), activins etc. Although many signals targeting GCs are known, the way these cells integrate this information at the transcriptional level is still poorly understood. For example,

Published by Bioscientifica Ltd. 


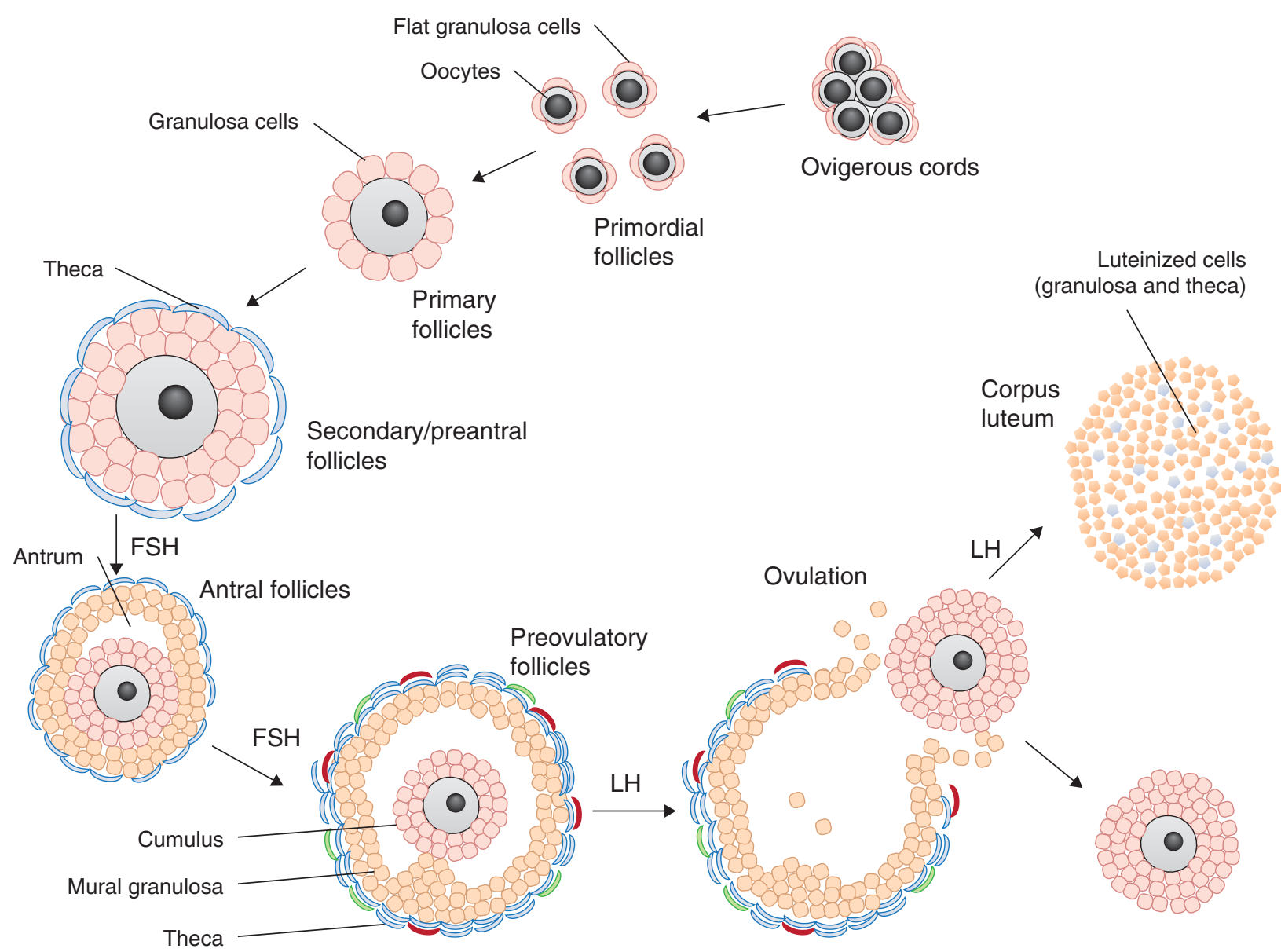

\section{Figure 1}

Outline of the main steps of folliculogenesis. Folliculogenesis starts with primordial follicles that are subsequently recruited to become primary follicles. Proliferating GCs progressively form several layers around the oocyte (secondary to late preantral follicles). From this stage, a layer of theca cells surrounds the follicle, and the follicles start to produce oestrogens. Theca cells produce androgens, which are converted into oestrogens in granulosa cells. Whereas follicular growth to the secondary/preantral stage is independent of gonadotrophins, progression beyond this stage strictly depends on FSH stimulation. As GC continue to

the reasons why GCs become dependent on FSH for their proliferation at the antral stage or the precise mechanisms by which the $\mathrm{FSH} / \mathrm{LH}$ surge triggers ovulation remain unclear. Similarly, the precise signal(s) triggering follicle recruitment for maturation are yet to be determined.

The dysregulation of GC differentiation is involved in major ovarian pathologies, such as primary ovarian insufficiency (POI), polycystic ovary syndrome (PCOS) or GC tumours (GCTs). POI is defined by the absence of menses during 4 consecutive months, low oestrogen levels and an abnormally high level of FSH occurring before the age of 40 years. Although these symptoms are close to those of menopause, it happens occasionally that ovarian proliferate, the antrum is formed and separates de facto granulosa cells into two general populations: cumulus and mural GCs. At this stage, selection occurs between growing follicles, and only one or a limited number of follicles continue growing to the preovulatory stage while others undergo atresia. Two layers of theca (theca interna and externa) can be distinguished around selected follicles. After ovulation, which is triggered by a peak of $\mathrm{FSH}$ and $\mathrm{LH}$, theca cells and mural granulosa cells luteinise to produce progesterone.

function can reappear and allow pregnancy (De Vos et al. 2011). Understanding the molecular mechanisms underlying GC differentiation may therefore provide insights into the pathogenesis and treatment of these diseases. Conversely, the identification of genetic determinants for these conditions may be highly informative in the study of ovarian function.

Although POI is a rather multifactorial condition, heterogenous genetic causes have been identified in familial and sporadic cases. Some of the altered genes are known for their role in folliculogenesis such as $F S H B$, FSHR, FOXO3A, ESR1, LHB, NR5A1, NOBOX and others (Qin et al. 2007, De Vos et al. 2011, Lakhal et al. 2012). 
An example of a gene associated with familial POI is the one encoding the transcription factor (TF) forkhead box L2 (FOXL2), whose mutations are responsible for the blepharophimosis ptosis epicanthus inversus syndrome (BPES), a dominant condition characterised by palpebral malformations associated with POI (type I) or not (type II). Mutations affecting this gene can be detected in about $90 \%$ of BPES patients and in $70 \%$ of them, the mutation is intragenic (Crisponi et al. 2001, Verdin \& De Baere 2012). FOXL2 is a single-exon gene encoding a protein of 376 amino acids. The protein contains a forkhead DNAbinding domain and a polyalanine tract of 14 residues, which is expanded to 24 residues in $30 \%$ of BPES cases with intragenic mutations (Cocquet et al. 2003, Verdin \& De Baere 2012). FOXL2 is highly conserved among vertebrates, undergoes strong purifying selection (Cocquet et al. 2003) and has emerged as a key factor of ovarian biology.

This review focuses on the transcriptional regulation of GC function, with a particular attention on the role of FOXL2 and its known transcriptional targets (summarised in Table 1). Recent studies have indicated its involvement in virtually all stages of ovarian development and function, as well as its central role in GC-related ovarian pathologies.

\section{Sex determination and early ovarian development}

Gonadal sex determination is genetically determined in mammals and involves the mobilisation of sex-specific transcriptional networks in the common precursors of Sertoli cells and GCs. In XY individuals, the first specific event of masculinisation is the expression of the TF SRY, encoded on the $\mathrm{Y}$ chromosome. This factor is expressed for a short period of time in the mouse (peaking at 11.5 days post-coitum (d.p.c.)) and is under the control of the TFs NR5A1 (also known as steroidogenic factor 1 (Sf-1)), Wilms tumour 1 (WT1) and the complex Gata-binding protein 4, friend of Gata 2 (GATA4-FOG2) (de Santa Barbara et al. 2001, Miyamoto et al. 2008). SRY, together with NR5A1, contributes to the activation of a gene encoding another TF from the same family, SRY-box 9 (SOX9), which regulates, in turn, genes essential for testis and genital development such as Fgf9, Dhh or Amh (Yao et al. 2002, Chaboissier et al. 2004, Hiramatsu et al. 2010). In mice, Sox9 is both necessary and sufficient for testis determination, whereas SRY would 'simply' upregulate Sox9 at the right time during development (Vidal et al. 2001, Barrionuevo et al. 2006).
In the absence of strong SOX9 expression, which is the case in XX individuals, transcriptional networks responsible for female development are activated. Several genes involved in ovarian determination/differentiation encode factors involved in $\beta$-catenin signaling. In particular, WNT4 and RSPO1, two secreted positive effectors of $\beta$-catenin signaling and of $\beta$-catenin expression, are required for the development of functional ovaries (Vainio et al. 1999, Chassot et al. 2008, Liu et al. 2009). Strikingly, $\beta$-catenin stabilisation is sufficient to induce femaleness in XY mice (Maatouk et al. 2008). This pathway seems to activate the follistatin gene (Fst), which encodes a secreted inhibitor of the TGF $\beta$ pathway, also necessary for ovarian development (Yao et al. 2004). Expression of ovarian genes, such as Wnt4 and Foxl2, is decreased in mice where $\beta$-catenin has been inactivated in Nr5a1-positive cells (including foetal GC precursors), although this may be due to a reduction of the pool of precursors. In addition to secreted inducers, activation of the $\beta$-catenin pathway also requires the presence of the GATA4-FOG2 complex. Indeed, in its absence, the inhibitor of the $\beta$-catenin signaling pathway DKK1 is highly expressed. Dkk1 deletion allows reactivation of the pathway, but is not sufficient to promote ovarian expression of Wht4 and Foxl2. This suggests the existence of a regulatory loop involving GATA4-FOG2 and the canonical pathway to promote an ovarian 'programme' (Manuylov et al. 2008). Finally, it is important to note that the $\beta$-catenin pathway and SRY/SOX9 repress each other, making them mutually exclusive (Bernard et al. 2008, Edson et al. 2009).

The role of FOXL2 during early ovarian development is less well understood. In the mouse, Foxl2 is the earliest known ovarian marker, its expression being detectable from 12.0 d.p.c. (Auguste et al. 2011). Nevertheless, Foxl2 ${ }^{-1-}$ mice develop normally until birth, and no perinatal sex reversal is observed (Schmidt et al. 2004, Uda et al. 2004). It has been suggested that (one of) its function(s) could be to 'cooperate' with BMP2 and WNT4 to activate Fst expression (Kashimada et al. 2011). Although FOXL2 is apparently not required during early ovarian development in mice, several studies suggest that it could play an important role in ovarian determination and development in other mammals. Indeed, a regulatory mutation in goats, responsible for the polled intersex syndrome ( PIS $^{-/}{ }^{-}$), which affects the expression of two transcripts, FOXL2 and polled intersex syndrome regulated transcript 1 (PISRT1), during ovarian development was identified in XX sex-reversed animals (Pailhoux et al. 2005). Further work showed that PISRT1 dysregulation could not explain the observed phenotype (Boulanger et al. 2008), suggesting that FOXL2

Published by Bioscientifica Ltd. 
Table 1 Overview of potential direct and indirect FOXL2 transcriptional targets

\begin{tabular}{|c|c|c|c|c|c|}
\hline Gene names & Overall functions & Effects of FOXL2 & Context & Methods & References \\
\hline \multirow[t]{5}{*}{ FST } & Ovarian development & Activation & Mouse pituitary cells & Overexpression & Blount et al. (2009) \\
\hline & Pituitary function & Activation & Mouse foetal ovaries & Knockout & $\begin{array}{l}\text { Garcia-Ortiz et al. (2009) } \\
\text { and Kashimada et al. } \\
(2011)\end{array}$ \\
\hline & Follicle growth & Activation & Mouse adult ovaries & Knockout & Uhlenhaut et al. (2009) \\
\hline & & Activation & Mouse granulosa cells & Overexpression & Kashimada et al. (2011) \\
\hline & & Activation & Human cells (COV434) & Overexpression & Nonis et al. (2013) \\
\hline \multirow[t]{2}{*}{ SOX9 } & Sex determination & Repression & Mouse adult ovaries & Knockout & Uhlenhaut et al. (2009) \\
\hline & & Repression & Human cells (KGN) & Knockdown & Rosario et al. (2012) \\
\hline \multirow[t]{7}{*}{ CYP19A1 } & Oestrogen production & Activation & $\begin{array}{l}\text { Goat promoter, } \\
\text { human cells (KGN) }\end{array}$ & Overexpression & Pannetier et al. (2006) \\
\hline & & Activation & Mouse adult ovaries & Knockout & Uhlenhaut et al. (2009) \\
\hline & & Activation & Human cells (KGN) & Knockdown & Rosario et al. (2012) \\
\hline & & Activation & Human cells (KGN) & Overexpression & Fleming et al. (2010) \\
\hline & & Repression & Hamster cells ( $\mathrm{CHO})$ & Overexpression & Bentsi-Barnes et al. (2010) \\
\hline & & Repression & $\begin{array}{l}\text { Mouse primary } \\
\text { granulosa cells }\end{array}$ & miRNA knockdown & Dai et al. (2013) \\
\hline & & Repression & Human cells (KGN) & Overexpression & Dai et al. (2013) \\
\hline \multirow[t]{2}{*}{ KITL } & Follicle activation & Activation & $\begin{array}{l}\text { Mouse foetal/new- } \\
\text { born ovaries }\end{array}$ & Knockout & Garcia-Ortiz et al. (2009) \\
\hline & & None & $\begin{array}{l}\text { Mouse newborn/adult } \\
\text { ovaries }\end{array}$ & Knockout & Schmidt et al. (2004) \\
\hline$C D K N 1 B$ & Follicle activation & Activation & $\begin{array}{l}\text { Mouse foetal/new- } \\
\text { born ovaries }\end{array}$ & Knockout & Garcia-Ortiz et al. (2009) \\
\hline SMAD3 & Signal transduction & Activation & $\begin{array}{l}\text { Mouse foetal/new- } \\
\text { born ovaries }\end{array}$ & Knockout & Garcia-Ortiz et al. (2009) \\
\hline BMPR1A & Signal transduction & Activation & $\begin{array}{l}\text { Mouse foetal/new- } \\
\text { born ovaries }\end{array}$ & Knockout & Garcia-Ortiz et al. (2009) \\
\hline$D K K 3$ & Signal transduction & Activation & $\begin{array}{l}\text { Mouse foetal/new- } \\
\text { born ovaries }\end{array}$ & Knockout & Garcia-Ortiz et al. (2009) \\
\hline \multirow[t]{2}{*}{ STAR } & Oestrogen production & Repression & $\begin{array}{l}\text { Human promoter/ } \\
\text { Hamster cells }\end{array}$ & Overexpression & Pisarska et al. (2004) \\
\hline & & Repression & Human cells (KGN) & Knockdown & Rosario et al. (2012) \\
\hline \multirow[t]{2}{*}{ CYP17A1 } & Androgen production & Repression & Human cells (KGN) & Knockdown & Park et al. (2010) \\
\hline & & Repression & Rat granulosa cells & Overexpression & Park et al. (2010) \\
\hline \multirow[t]{2}{*}{ PTGS2 } & Ovulation & Activation & Human cells (KGN) & Overexpression & Batista et al. (2007) \\
\hline & & Repression & $\begin{array}{l}\text { Human cells (293FT } \\
\text { and MDA-MB-231 } \\
\text { cells) }\end{array}$ & Overexpression & Kim et al. (2009) \\
\hline SERPINE2 & Ovulation & Activation & $\begin{array}{l}\text { Mouse foetal/adult } \\
\text { ovaries }\end{array}$ & Knockout & Caburet et al. (2012) \\
\hline HAS2 & Ovulation & Repression & $\begin{array}{l}\text { Mouse foetal/new- } \\
\text { born ovaries }\end{array}$ & Knockout & Caburet et al. (2012) \\
\hline PTGER2 & Ovulation & Activation & $\begin{array}{l}\text { Mouse foetal/new- } \\
\text { born ovaries }\end{array}$ & Knockout & Caburet et al. (2012) \\
\hline EDNRA & Ovulation & Activation & Mouse adult ovaries & Knockout & Caburet et al. (2012) \\
\hline \multirow[t]{4}{*}{$F S H B$} & Follicle growth & Activation & Mouse pituitary & Knockout & $\begin{array}{l}\text { Justice et al. (2011) and } \\
\text { Tran et al. (2013) }\end{array}$ \\
\hline & & Activation & $\begin{array}{l}\text { Porcine promoter, } \\
\text { mouse pituitary cells } \\
\text { (LbT2) }\end{array}$ & Overexpression & Tran et al. (2011) \\
\hline & & Activation & Mouse pituitary cells & Overexpression & $\begin{array}{l}\text { Lamba et al. (2009) and } \\
\text { Tran et al. (2011) }\end{array}$ \\
\hline & & Activation & $\begin{array}{l}\text { Human promoter, } \\
\text { mouse pituitary cells } \\
\text { (LbT2) }\end{array}$ & Overexpression & Corpuz et al. (2010) \\
\hline$T N F-R 1$ & Apoptosis & Activation & Human cells (KGN) & Overexpression & Kim et al. (2011) \\
\hline FAS & Apoptosis & Activation & Human cells (KGN) & Overexpression & Kim et al. (2011) \\
\hline$T R A I L-R$ & Apoptosis & Activation & Human cells (KGN) & Overexpression & Kim et al. (2011) \\
\hline
\end{tabular}


Table 1 Continued

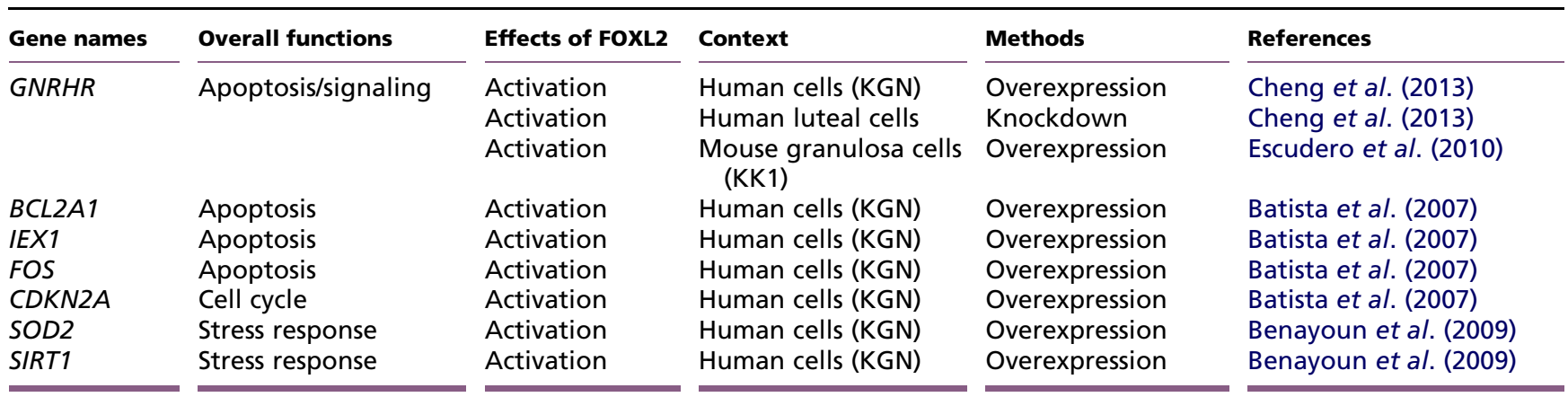

misexpression is the responsible event. However, FOXL2 inactivation during foetal development in the goat is still required to formally demonstrate this very plausible hypothesis. This would epitomise dramatic species-specific differences because neither in human nor in mouse are FOXL2 mutations (thus far) known to lead to overt sex reversal.

Recent studies have shown that sexual identity is maintained at the cellular level throughout adulthood in mice. Thus, deletion of the TF Dmrt1 in Sertoli cells of adult XY mice results in Foxl2 expression and transdifferentiation of Sertoli cells into granulosa-like cells (Matson et al. 2011). Reciprocally, FOXL2 is required to maintain GC identity in females. Indeed, a deletion of Foxl2 in GCs in adult mice leads to the expression of Sertoli-cell markers and to the appearance of structures reminiscent of seminiferous tubules, in the ovary (Uhlenhaut et al. 2009). A similar phenotype has been described in mice where oestrogen receptors Esr1 and Esr2 are deleted, or where oestrogen production is impaired, suggesting a functional synergy between oestrogen receptors and FOXL2 in the maintenance of GC identity (Fisher et al. 1998, Dupont et al. 2000). Interestingly, FOXL2 interacts directly with both oestrogen receptors and, along with ESR1, it directly represses a testis-specific enhancer of Sox9 in mouse (Uhlenhaut et al. 2009).

FOXL2 has been described in various species as a positive regulator of Cyp19a1, which encodes the aromatase, responsible for the last step of oestrogen production in GCs (Pannetier et al. 2006, Uhlenhaut et al. 2009, Fleming et al. 2010, Rosario et al. 2012). This suggests that FOXL2 can influence directly and indirectly oestrogen signaling. As already noted, in addition to its role in repressing Sox9, FOXL2 is also required for the expression of FST, which is involved in follicle assembly (Kashimada et al. 2011, Caburet et al. 2012). Interestingly, Fst deletion in proliferating GCs causes premature depletion of the ovarian reserve and formation of Sertoli-like cells in the ovary, quite similar to the phenotype observed for the deletion of Foxl2, suggesting that Fst could be a key target of FOXL2 (Jorgez et al. 2004, Yao et al. 2004). The role of FOXL2 in the maintenance of GC identity and oestrogen signaling in murine ovaries could explain the differences between the phenotypes of Foxl2 $2^{-1-}$ mice, where ovaries develop apparently normally until birth, and PIS $^{-1-}$ goats, in which decreased FOXL2 expression would induce XX-sex reversal. However, note that despite their normal appearance, Foxl2 $2^{-1-}$ ovaries upregulate male markers such as Sox9 or Inhbb during late developmental stages, suggesting a molecular loss of identity of pre-GCs, without overt macroscopic consequences (Garcia-Ortiz et al. 2009).

\section{Follicle activation and GC differentiation}

During foetal development, germ cells are organised in clusters (ovigerous cords) surrounded by somatic cells of the GC lineage. A large proportion of the germ cells undergoes apoptosis, while pre-GCs invade the interstices between germ cells to form a single layer around each surviving oocyte. Once formed, these primordial follicles enter a quiescent state in which they can stay for years or decades. After a first wave of folliculogenesis, reactivation of the primordial follicles takes place progressively during mature sexual life. The number of activated follicles is connected to the ovarian reserve and to the mono- or polyovulating capacity of the species in question. Deregulation of primordial follicle activation can thus cause depletion of the ovarian reserve and lead to premature menopause (Adhikari \& Liu 2009). This process is finely regulated but the nature of the signal(s) triggering primordial follicle activation has remained elusive for years. Studies on the molecular mechanisms involved suggest that the communication between GCs and the oocyte is a key aspect of this process (Adhikari \& Liu 2009).

Several factors are required for primordial follicle activation (Fig. 2). This is the case for the secreted factor

Published by Bioscientifica Ltd 
A

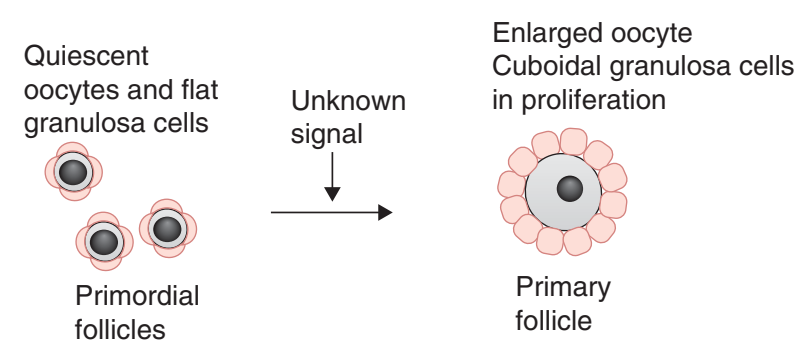

B

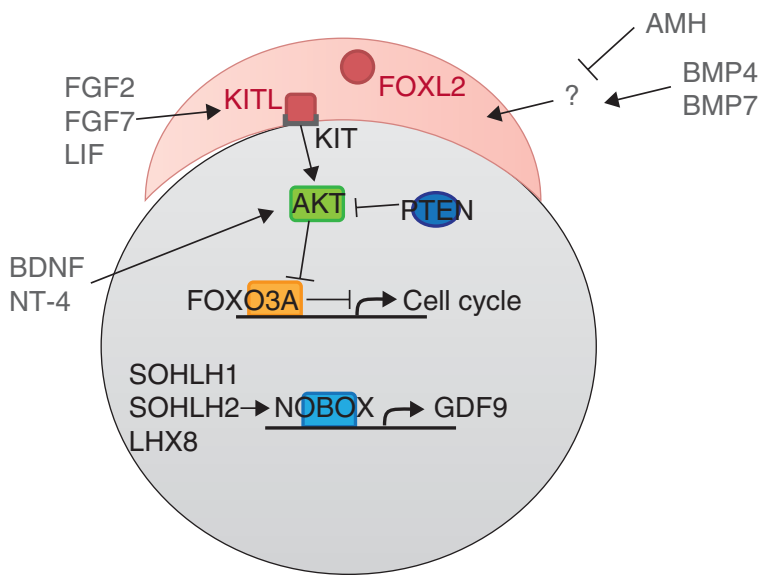

Figure 2

Overview of some factors implicated in follicle recruitment for maturation. (A) Summary and representation of principal macroscopic changes between primordial and primary follicles. (B) Representation of the principal factors implied to be involved in primordial follicle activation, and their relations, when they are known. Ooocyte-transcribed factors are in black, granulosa-transcribed factors are in red and factors originating from other follicles or of unknown origin are in grey. Activation is represented by an arrow and repression by a blunt arrow.

c-Kit ligand (KITL, also known as stem cell factor), produced by GCs, and its receptor KIT expressed by the oocytes. Indeed, a Kit receptor-blocking antibody strongly prevents activation of primordial murine follicles (Yoshida et al. 1997). Conversely, treatment of explanted rat ovaries with KITL increases primordial follicle recruitment (Parrott \& Skinner 1999). Mice with mutations of the Kit receptor have follicles blocked at the primary stage, suggesting that GCs can start their differentiation but that the oocyte does not exit quiescence (Huang et al. 1993). Stimulation of the oocyte by KITL in rodents seems to activate the PI3K/AKT pathway leading to the inactivating phosphorylation of the TF FOXO3A (Reddy et al. 2005). This is consistent with the role of FOXO3A and PTEN, an inhibitor of the PI3K/AKT pathway, in the preservation of oocyte quiescence. Oocyte-specific Pten knockout results in a constitutive activation of the
PI3K/AKT pathway and in a global activation of primordial follicles in the weeks following birth (John et al. 2008, Reddy et al. 2008). Other factors signaling through PI3K/AKT could also be involved in follicle activation. For example, the NTRK2 receptor, expressed in the oocytes of primordial follicles, and its ligands BDNF and NT-4 are also necessary for the recruitment of primordial follicles in mice (Paredes et al. 2004). Also, other growth factors, such as FGF2, LIF or FGF7, could modulate primordial follicle recruitment by modulating KITL expression (Nilsson et al. 2002, Nilsson \& Skinner 2004, Kezele et al. 2005). Normal follicle activation also requires the expression of several oocyte-specific or -enriched TFs such as SOHLH1, SOHLH2, LHX8 and NOBOX. Indeed, their absence results in follicles arrested at the primary stage in mice (Rajkovic et al. 2004, Pangas et al. 2006, Choi et al. 2008a,b).

The AMH produced by the GCs of the primaryto-antral follicles is a key factor for the maintenance of the ovarian reserve (Baarends et al. 1995). AMH represses primordial follicle activation, suggesting the existence of a negative feedback mechanism avoiding anarchic follicle recruitment. Indeed, $\mathrm{Amh}^{-1-}$ mice display greater recruitment of primordial follicles and depletion of the follicular reserve (Durlinger et al. 1999). Conversely, treatment of explanted human ovaries or rat neonatal ovaries with recombinant $\mathrm{AMH}$ in vitro leads to a decreased recruitment of primordial follicles (Carlsson et al. 2006, Nilsson et al. 2007). AMH is thought to induce the activation of the BMP-dependent effectors SMAD1, SMAD5 and SMAD8. Interestingly, however, other BMP factors (i.e. BMP4 or BMP7) play an activating role in follicle recruitment in rats (Lee et al. 2001, Nilsson \& Skinner 2003), and it has been suggested that AMH may diminish the production of BMP4 and other stimulatory factors (Nilsson et al. 2007). Further work is required to identify the precise molecular mechanisms underlying such processes probably involving combinatorial control.

Few determinants of GC differentiation at the transcriptional level have been described so far and FOXL2 is one of them. As previously mentioned, Foxl2 $2^{-1-}$ mice develop normally until birth, at least in appearance. However, examination of their ovaries 2 weeks after birth reveals the presence of follicles with large oocytes surrounded by a single layer of flat GCs, and the absence of normal follicles at later maturation stages (Schmidt et al. 2004, Uda et al. 2004). In the following weeks, massive 'follicle activation' seems to occur, but no cuboidal GCs are observed. The oocytes of these 'activated' follicles quickly undergo apoptosis, provoking a depletion of the follicular reserve (Schmidt et al. 2004, Uda et al. 2004).

Published by Bioscientifica Ltd. 
This mouse phenotype is reminiscent of human POI, suggesting that FOXL2 plays a similar role in humans. Indeed, in vitro functional analyses of intragenic FOXL2 mutations suggest that POI (type I BPES) is associated with the loss of FOXL2 transcriptional activity (Dipietromaria et al. 2009). FOXL2 haploinsufficiency in humans seems therefore to cause a milder version of the mouse phenotype. A recent analysis used these observations to propose a structural model to predict the outcome (i.e. the occurrence of POI) of FOXL2 mutations when they are located in the DNA-binding domain, thus offering the first tool for genetic counseling of young female BPES patients (Todeschini et al. 2011).

The nature of the transcriptional targets of FOXL2 in the pre-GCs has not been characterised in detail. An analysis of the ovarian transcriptome during the foetal period in Foxl2 $2^{-1-}$ mice suggested that Kitl may be one of the transcriptional targets of FOXL2 during this period (Garcia-Ortiz et al. 2009). This is, however, in contradiction with another work that used in situ hybridsation to show that Kitl expression was normal in the ovaries of young and adult Foxl2 ${ }^{-l-}$ mice (Schmidt et al. 2004). Other potential targets of FOXL2 in mouse foetal ovaries have been described (Garcia-Ortiz et al. 2009), although they may also reflect indirect effects of the absence of FOXL2. One of the most relevant FOXL2 targets suggested by this study may be the cell cycle inhibitor $C d k n 1 b$, expressed in both oocytes and pre-GCs. The deletion of $C d k n 1 b$ in mice leads to an increased recruitment of primordial follicles and to a depletion of the follicular reserve before the age of three months (Rajareddy et al. 2007). FOXL2 could help maintaining granulosa quiescence by activating $C d k n 1 b$, but it is not clear whether this is related to its role in GC differentiation. Other potentially interesting FOXL2 targets include the TGF $\beta$ effector Smad3, the BMP/AMH receptor Bmpr1a and the $\beta$-catenin repressor $D k k 3$, although an in depth analysis is required to characterise the in vivo effect of each of these factors, and others, in GC differentiation (Garcia-Ortiz et al. 2009).

\section{Putative roles of FOXL2 during folliculogenesis}

Owing to the loss of functional GCs in Foxl2 knockout models, it is hard to determine whether FOXL2 also plays a role in other aspects of folliculogenesis, such as follicular growth, oestrogen production or ovulation (Cocquet et al. 2002, Schmidt et al. 2004). The examination of FOXL2 transcriptional targets in various contexts suggests that
FOXL2 may be important in many ovarian processes. Several transcriptomic studies on human GCT-derived cells or mice ovaries at different stages of development have described many potential targets of FOXL2 (Batista et al. 2007, Garcia-Ortiz et al. 2009, Uhlenhaut et al. 2009, Escudero et al. 2010, Rosario et al. 2012). These studies are limited, in the case of GCT-derived cells by the fact that the mutation or extinction of FOXL2 can affect cell identity in the long-term, and 'in the case of mouse ovaries' by the major morphological changes associated with the absence of FOXL2 and by the superposition of direct and indirect effects on multiple cell types (Caburet et al. 2012).

FOXL2 regulates several key genes necessary for oestrogen production. As previously mentioned, FOXL2 activates the expression of CYP19A1 in several mammalian models, including goat and mouse ovaries and human cells (Pannetier et al. 2006, Uhlenhaut et al. 2009, Fleming et al. 2010). Some studies have, however, suggested the existence of a repressive effect of FOXL2 on the expression of CYP19A1 in hamster and mouse cells, but an explanation for this difference is lacking (Pisarska et al. 2011, Dai et al. 2013). FOXL2 also regulates other enzymes of steroidogenesis. One of its first described targets is the gene encoding StAR, involved in intramitochondrial cholesterol transport, whose expression is repressed by FOXL2 in human cells (Pisarska et al. 2004, Rosario et al. 2012). FOXL2 also represses, in a human GCT-derived cell line, the CYP17A1 gene, which encodes an enzyme responsible for androgen synthesis in the theca cells (Park et al. 2010). This suggests that FOXL2 can repress theca-specific genes in GCs, but in vivo confirmation is required.

FOXL2 may also regulate genes playing an essential role in late folliculogenesis. For example, FOXL2 overexpression in GCT-derived cells causes induction of prostaglandin synthase (or COX2), but it has also been showed that it could repress the induction of this gene by ESR1 in breast cancer or embryonic kidney cells (Batista et al. 2007, Kim et al. 2009), which could be due to a different cellular context. Mouse ovarian transcriptomic studies suggest, in addition, that FOXL2 regulates the expression of genes involved in ovulation such as Serpine2, Has2, Ptger2 or Ednra (Caburet et al. 2012). FOXL2 may thus be required for the acquisition and maintenance of a normal transcriptional programme in GCs of the preovulatory follicles. However, further data are required to determine in vivo whether FOXL2 has a role in late folliculogenesis.

In addition to its direct role in GC function in the ovary, FOXL2 may also play a role in folliculogenesis

Published by Bioscientifica Ltd. 
through its expression in the pituitary. Indeed, recent studies in mice have shown that FOXL2 is required for the production of FSH in gonadotrope cells. FOXL2 coregulates with SMAD3, an effector of activin in gonadotrope cells, the transcription of the Fshb gene, encoding the specific subunit of FSH (Lamba et al. 2009, 2010, Corpuz et al. 2010, Tran et al. 2011). Accordingly, the knock-out of Foxl2, constitutively or only in gonadotrope cells, leads to a defect in FSH production (Justice et al. 2011, Tran et al. 2013). Interestingly, cooperation of FOXL2 with SMAD3 is also observed on the promoter of the Fst gene in the pituitary and GCs (Blount et al. 2009, McTavish et al. 2013). Thus, SMAD3 seems to be a key partner of FOXL2 in several contexts.

Altogether, these observations suggest that FOXL2 may act as a global regulator of folliculogenesis, beyond its most obvious role in GC differentiation. It might therefore be interesting to examine its potential role in ovarian pathologies such as PCOS, and isolated POI.

\section{FOXL2: a key player in GC proliferation and tumorigenesis}

GCTs are by far the most common type of sex cord tumours and represent up to $5 \%$ of ovarian cancers. This type of cancer is also the most common ovarian cancer in other mammals, such as the mare, and appears spontaneously in certain strains of mice (Beamer et al. 1985, McCue et al. 2006). These tumours can cause hyperoestrogenism, resulting in various symptoms such as disturbance of menstruation or uterine bleeding after menopause (Tavassoli et al. 2003). There are two types of GCTs, classified according to their age of onset and histological features. The 'juvenile GCTs' account for 5\% of the cases and usually occur before puberty, while the 'adult-type' tumours most often occur during perimenopause or after menopause. The prognosis of these tumours is generally favourable, but aggressive recurrence, usually fatal, occurs in $10-50 \%$ of cases. In addition, these tumours are slow growing and can reccur several decades after removal of the primary tumour, requiring long-term monitoring of patients (Tavassoli et al. 2003).

FOXL2 misexpression has been detected in juvenile GCTs. Indeed, the expression of FOXL2 is reduced or extinct in some juvenile GCTs, correlating with an aggressive phenotype (Kalfa et al. 2007). A recent study using NextGen sequencing has identified a recurrent somatic mutation in the coding sequence of FOXL2 in 97\% of adult-type tumours (Shah et al. 2009). This substitution of one base in the coding sequence of
FOXL2 (c.402>G) results in a p.C134W substitution at the protein level. This mutation was not found in healthy cells of the ovary or other tissues, indicating that the mutation occurs during tumorigenesis (Shah et al. 2009). Several studies have confirmed the high prevalence of this mutation and its specificity to adult-type GCTs. Over $94 \%$ of GCTs carry this mutation, and it has been suggested that the remaining ones are misdiagnosed sex cord tumours (Jamieson et al. 2010, Jamieson \& Fuller 2012). The mutation was however identified in $20 \%$ of tested thecomas and also in GCTs of the testis (Jamieson \& Fuller 2012, Lima et al. 2012).

FOXL2 regulates, directly and indirectly, genes involved in cell proliferation and apoptosis. Its overexpression in GCT-derived cells upregulates pro-apoptotic genes, such as TNF-R1, FAS or TRAIL-R, receptors of proapoptotic ligands (Kim et al. 2011). FOXL2 also activates the expression of the GNRH receptor in human and mouse GCs, which may play a pro-apoptotic role (Escudero et al. 2010, Cheng et al. 2013). The pro-apoptotic role of FOXL2 has mainly been studied in GCT cells, and has not been demonstrated in vivo yet. FOXL2 may also have an antiproliferative role in regulating the cell cycle as it has been reported to activate the cycle inhibitor CDKN2A and to inhibit cyclin D2 (Batista et al. 2007, Bentsi-Barnes et al. 2010). Finally, FOXL2 could play a role in the oxidative stress response by regulating the expression of genes such as SIRT 1 and SOD2 by directly binding to their promoters as shown in GCT-derived cells (Benayoun et al. 2009). Several studies have been conducted to elucidate how the $\mathrm{C} 134 \mathrm{~W}$ mutation is involved in tumorigenesis. The cysteine 134 of FOXL2 is located in the DNA-binding domain, and structural models suggest that the mutation does not directly affect DNA binding, but most probably the interaction with partners. Indeed, the $\mathrm{C} 134 \mathrm{~W}$ mutation does not cause a general loss of function in vitro and the mutated protein can activate normally most target promoters under conditions of overexpression (Benayoun et al. 2010). However, FOXL2 C134W has a decreased pro-apoptotic capacity when overexpressed in GCT-derived cultured cells (Kim et al. 2011). It has recently been suggested that deregulation of the expression of gonadotrophin-releasing hormone receptor (GNRHR) could contribute to the impairment in induction of apoptosis (Cheng et al. 2013). FOXL2-C134W has also been shown to overactivate the CYP19A1 promoter, compared with the WT version, although the link with tumorigenesis is not clear. A genomic exploration identified an enrichment of FOXL2 transcriptional targets involved in modulating apoptosis and the cell cycle

Published by Bioscientifica Ltd. 
among genes deregulated in adult GCT samples, compared with healthy (stimulated) GCs (Benayoun et al. 2013). A recent study has analysed the transcriptomic differences when FOXL2, WT or mutated, was overexpressed in juvenile GCT-derived cells. This study indicates that the mutation could affect the regulation of the TGF $\beta$ pathway by FOXL2, promoting the expression of genes of the TGF $\beta /$ activin/SMAD2/3 pathway, repressing the expression of genes of the BMP/SMAD1/5 pathway and thus promoting GC proliferation (Rosario et al. 2012). However, the molecular mechanism(s) by which the mutation induces these effects have not yet been characterised. Interestingly, it has recently been observed that the $C 134 \mathrm{~W}$ mutation reduced the ability of FOXL2 to induce the transcription of the FST gene in cooperation with SMAD2/3, although it did not prevent the association of FOXL2 with SMAD3 (Nonis et al. 2013). We observe a very similar effect on an artificial promoter possessing three repeats of an AP-1/SMAD3/FOXL2 composite element found in the murine promoter of the GNRH receptor (3XGRAS; Ellsworth et al. 2003; Fig. 3). Using a constitutively active version of the TGFBR1 (TGFBR1-CA), we stimulated SMAD2 and SMAD3 in presence or absence of FOXL2, in COV434 cells. This led to a moderate activation of the 3XGRAS promoter, which increased in the presence of FOXL2. Overexpression of SMAD7, which binds to the receptor and prevents SMAD2/3 phosphorylation, led to the inhibition of 3XGRAS activation by FOXL2, confirming that the observed effect was SMAD2/ 3-dependent. Because COV434 cells express SMAD2 around ten times more than SMAD3 at the RNA level, we overexpressed SMAD3 to test the effect of a change in the SMAD2/SMAD3 balance. As expected, this led to a hyperactivation of 3XGRAS promoter, but interestingly mutated FOXL2 had a strongly decreased ability to upregulate 3XGRAS under these conditions. The same experiment in KGN cells, without SMAD3 overexpression, recapitulated the results obtained in COV434 cells with SMAD3 overexpression. This is probably due to the higher level of SMAD3 in KGN cells. This experiment and the one described by Nonis et al. (2013) suggest that FOXL2 C134W has a decreased ability to cooperate with SMAD3 in GCs. It would be interesting to quantify the affinity of WT and mutant FOXL2 for SMAD3, and their ability to recognise composite elements to identify the source of this reduced cooperation. A recent study has also revealed results indicative of a lower capacity of mutated FOXL2 to synergise with transcriptional partners such as NR2C1 or GMEB1, although the ability of mutant FOXL2 to interact with these proteins, at least in conditions of overexpression, was retained (L'Hôte et al. 2012). Altogether, these observations suggest that the $C 134 \mathrm{~W}$ mutation affects functional interactions of FOXL2 with its partners.

The transcriptomic profile of adult GCTs suggests that they come mainly from proliferating GCs of antralto-preovulatory follicles. They express the FSH receptor and proliferate in response to FSH stimulation (Jamieson \& Fuller 2012). The pathways involved in the proliferation and/or apoptosis of GCs in antral follicles are therefore potentially involved in the genesis of adult GCT. They involve notably the PKA/CREB, PI3K/AKT, MAPK/ERK, $\beta$-catenin and TGF $\beta$ pathways, as epitomised by several mouse models that develop GCTs. For instance, deletion of Inha, which causes an absence of inhibin production, induces GCT formation with full penetrance, suggesting that inhibin is required to limit GC proliferation (Matzuk et al. 1992). Interestingly, deletion of Smad1 and Smad5 in GCs leads to a similar phenotype, suggesting that the $\mathrm{BMP} / \mathrm{SMAD}$ pathway is required to control GC proliferation (Pangas et al. 2008). This is confirmed by the observation that a double Bmpr1a/Bmpr1b knockout also leads to GCT formation (Edson et al. 2010).

In another model of tumorigenesis, a constitutively active mutant of $\beta$-catenin was specifically expressed in GCs. These mice developed abnormal follicles with the presence of tumours in 57\% of cases (Boerboom et al. 2005). Hypersecretion of LH also leads to GCTs in mice (Risma et al. 1995). Secondary inactivation of genes in these models has indicated various factors influencing the progression of GCTs. Thus, deletion of the genes coding the oestrogen receptors Esr1 and/or Esr2 in Inha ${ }^{-1-}$ mice leads to earlier and more aggressive tumour formation (Burns et al. 2003). Inactivation of Pten in mice where $\beta$-catenin is constitutively active also leads to a worsening of the tumour phenotype, suggesting that the PI3K/AKT pathway can be effectively mobilised in GCTs (Richards et al. 2012). More surprisingly, deregulation of the ERK pathway in the same mice, through the use of a Kras mutant, also leads to a worsening of the phenotype, while the introduction of this mutation into WT mice leads to cell cycle arrest in GCs (Richards et al. 2012). The MAPKs, particularly ERK, could thus play an important role in tumorigenesis of GCs. Several studies suggest that the ERK pathway is constitutively active in cell lines derived from GCTs, and inhibition of ERK1/2 by RNA interference can induce growth arrest of KGN cells (Steinmetz et al. 2004, Jamieson \& Fuller 2012). However, the mutation of FOXL2 remains the main marker of adult-type GCTs, most of which express the INHA gene and do not display constitutive activation

Published by Bioscientifica Ltd. 


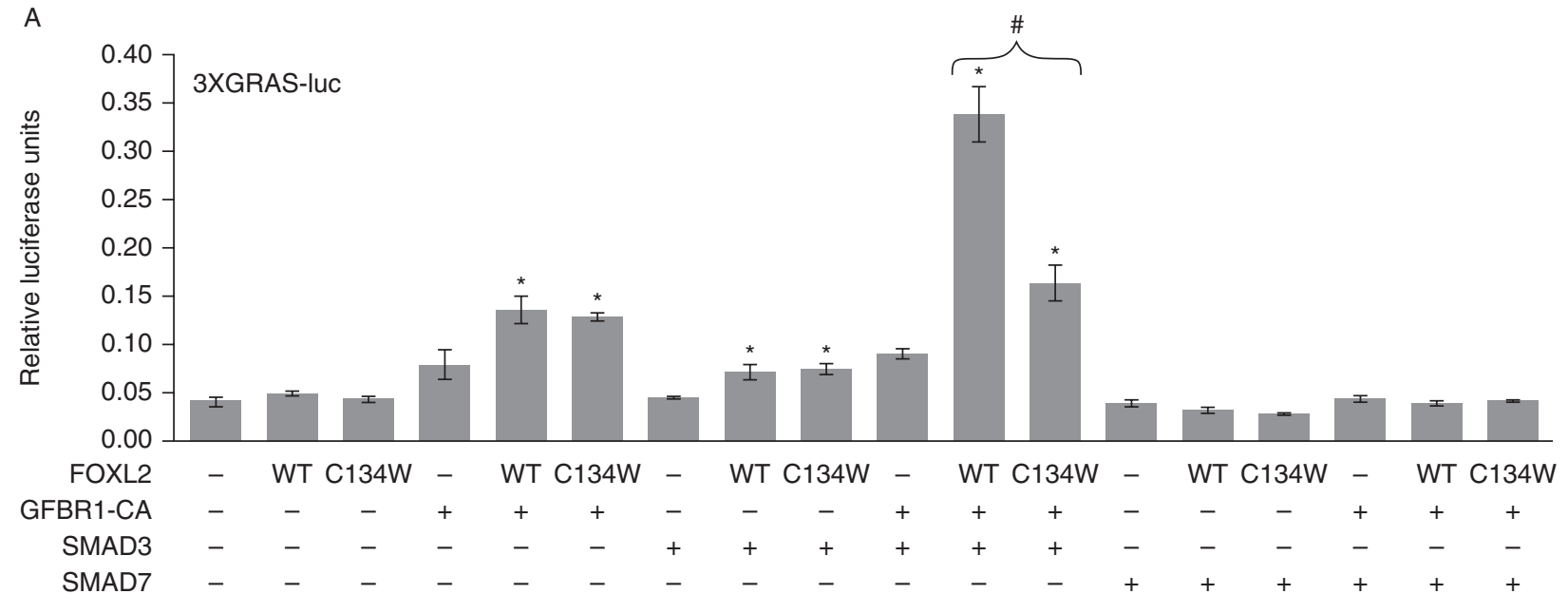

B

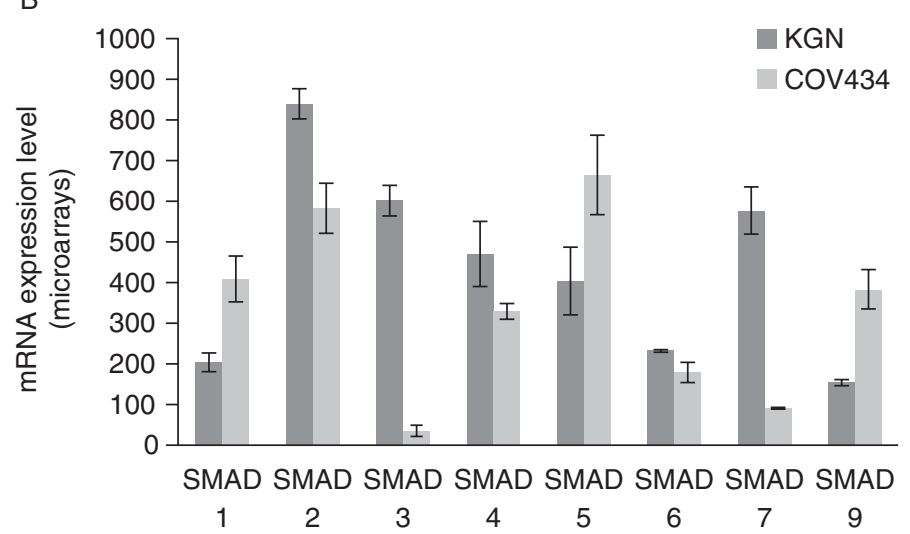

C

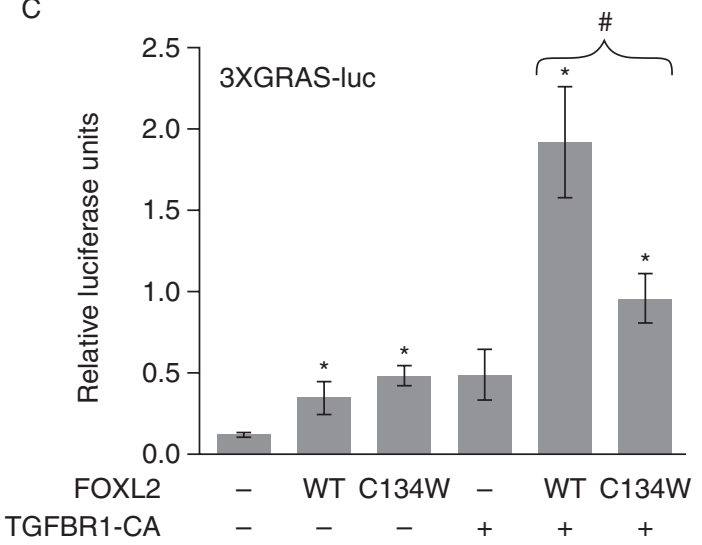

\section{Figure 3}

Mutant FOXL2 fails to cooperate with SMAD3 on a composite regulatory element. (A) Luciferase activity of the reporter promoter 3XGRAS-luc in COV434 cells. Reporter vector (400 ng) was co-transfected with $200 \mathrm{ng}$ of each of FOXL2 WT or C134W, TGFBR1-CA, SMAD3 and SMAD7, or PCDNA3.1 control vector, as indicated. Error bars represent the s.D. of five replicates. Asterisks represent a Student's $t$-test $P$ value $<10^{-3}$ between the indicated condition and control condition. The \# symbol indicates a Student's $t$-test $P$ value $<10^{-3}$ between the FOXL2 WT and mutant conditions.

(B) Expression value of SMAD1-9 mRNAs in COV434 cells and KGN cells, determined from microarray data (GEO datasets GSE39890 from

of $\beta$-catenin (Watson et al. 1997, Ohishi et al. 2011). This suggests that mouse models might be more representative of the juvenile type of GCTs. Further studies on the functional interactions of FOXL2 with these pathways are required to achieve a better understanding of GC tumorigenesis.

\section{Regulation of FOXL2 expression and function}

During mouse development, FOXL2 is expressed from 12 d.p.c. in the female genital ridge. Its expression seems Printed in Great Britain
Rosario et al. (2012)). Error bars represent the s.D.s of three conditions. (C) Luciferase activity of the reporter promoter 3XGRAS-luc in KGN cells. Reporter vector ( $400 \mathrm{ng}$ ) was co-transfected with $300 \mathrm{ng}$ of each of FOXL2 WT or C134W, TGFBR1-CA or pCDNA3.1 control vector, as indicated. Error bars represent the S.D. of five replicates. Asterisks represent a Student's $t$-test $P$ value $<10^{-3}$, between the indicated condition and control condition. The \# symbol indicates a Student's $t$-test $P$ value $<10^{-3}$ between the FOXL2 WT and mutant conditions. Experiments were led as in L'Hôte et al. (2012) and Benayoun et al. (2013).

to require the GATA4-FOG2 complex and activation of the $\beta$-catenin pathway. However, factors regulating FOXL2 expression directly are largely unknown and the decreased FOXL2 expression in the various animal models mentioned above could be related to the decrease in the cell population expressing it (Manuylov et al. 2008). The developmental expression of FOXL2 is also reduced in Cited $2^{-1-}$ mice. It has been suggested that this could be an indirect effect via the effect of CITED2 on Nr5a1 (Combes et al. 2010) required for gonadal and other steroidogenic tissue formation. However, the observed effect on FOXL2 
could also result from the reduction of the pool of GC precursors in Cited $2^{-1-}$ mice.

Few TFs have been shown to directly regulate the expression of FOXL2. One of them is FOXL2 itself, which binds to its promoter to activate its own transcription, at least in vitro (Moumné et al. 2008). Another factor potentially regulating FOXL2 expression is retinoblastoma 1 (RB1). In the mouse, depletion of RB in GCs leads to an increase of follicle recruitment followed by massive follicular atresia and early depletion of the ovarian reserve. FOXL2 expression is reduced in the ovaries of $R b^{-1-}$ mice, suggesting a direct or indirect control (Andreu-Vieyra et al. 2008). Data from the ENCODE consortium (http://genome.ucsc.edu/) show binding of the RB-associated TFs ELF1, E2F1 and E2F6 to the FOXL2 proximal promoter, indicating a potential regulation by these factors. It would be interesting to study in detail the regulation of FOXL2 expression by RB and its partners, and also to determine whether FOXL2 expression is cellcycle-dependent, as is the case for most RB-E2F targets (Poznic 2009).

Two recent studies have suggested that FOXL2 expression could also be regulated by miRNAs binding to its $3^{\prime}$ UTR. Rosario et al. proposed that the difference observed in FOXL2 expression in two GC lines (COV434 and KGN) could be due to the action of miR17 family miRNAs. Such miRNAs could negatively regulate FOXL2 expression. The authors show that such miRNAs are expressed in COV434 cells, in which FOXL2 is absent, but are absent in KGN cells, in which FOXL2 is expressed, and that they regulate FOXL2 expression in a $3^{\prime}$ UTRdependent way (Rosario et al. 2013). However, no miR17binding site could be detected in FOXL2 mRNA, and it was proposed that the observed effect could be indirect. The second study, performed by Dai et al., involves miR133b. Treatment of mouse primary GCs or human KGN cells with miR133b decreased Foxl2 expression. Moreover, miR133b inhibited the observed Foxl2-mediated transcriptional repression of STAR and CYP19A1 in KGN cells (Dai et al. 2013). The effect of miR133b on Foxl2 expression seems to rely on its $3^{\prime}$ UTR where putative binding sites were described, but direct binding is yet to be demonstrated.

The regulation of the FOXL2 expression and function can also involve post-translational modifications. The analysis by two-dimensional electrophoresis of the FOXL2 migration pattern suggests that the protein is highly modified post translationally (Benayoun et al. 2009). Several modified residues have been identified using mass spectrometry with overexpressed FOXL2.
Serine 33 appears to be one of the principal phosphorylated residues, other phosphorylated sites include serine 211 or tyrosine 215 , serine 238 and serine 323 or 326 . Interestingly, all in vitro-phosphorylated serine residues lie in a similar consensus PxSP, corresponding to the prefered site of MAPKs and structurally related kinases (Georges et al. 2011). Acetylation was detected on lysines 96, 114 and 366. The origins and exact roles of these modifications are still poorly understood. However, acetylation has been proposed to be necessary for activation by FOXL 2 of a fraction of its target genes, while some targets would be more sensitive to less acetylated FOXL2. The deacetylase SIRT1, which interacts with FOXL2, could thus directly regulate the activity of FOXL2 (Benayoun et al. 2009, L'Hôte et al. 2012). An enzyme proposed to phosphorylate FOXL2 is the kinase LATS1, which interacts directly with the former. Inactivation of LATS1 with an interfering RNA results in a decreased level of FOXL2 phosphorylation and in a weaker repressive activity of FOXL2 on a reporter promoter (Pisarska et al. 2010). LATS1 is a tumour suppressor and a regulator of the HIPPO pathway, which is involved in many types of cancer (Liu et al. 2012). Lats1 depletion in mice results in an almost complete absence of antral follicles, anovulation and in ovarian tumours of stromal origin. It has been suggested that infertility could be a side effect of the tumours (St John et al. 1999). FOXL2 interacts directly with the SUMO ligases PIAS1 and UBC9 (Kuo et al. 2009). Several potentially SUMOylated FOXL2 residues have been identified and it is not certain that this modification affects any residue in particular. SUMOylation seems to stabilise FOXL2 and consequently increases its transcriptional (activation or repression) activity (Kuo et al. 2009, Marongiu et al. 2010, Georges et al. 2011). Another consequence of SUMOylation under overexpression conditions is an increased recruitment of FOXL2 to PML nuclear bodies. FOXL2 recruitment to these bodies should be necessary to its stabilisation (Georges et al. 2011). However, confirmation of these findings in vivo is still required.

Beyond the regulation of its expression, FOXL2 function may be regulated through interactions with other proteins. It can form homo-dimers (multimers?), but it is not known whether they are transcriptionally active or not (Lamba et al. 2009). The binding sites identified so far suggest a monomeric binding of FOXL2 (Lamba et al. 2009). It has been suggested that FOXL2 multimerisation could induce dominant negative effects (Kuo et al. 2011). Indeed, it is known that aggregates formed by some FOXL2 mutants can trap the WT protein (Moumné et al. 2008). FOXL2 also interacts with the

Published by Bioscientifica Ltd. 

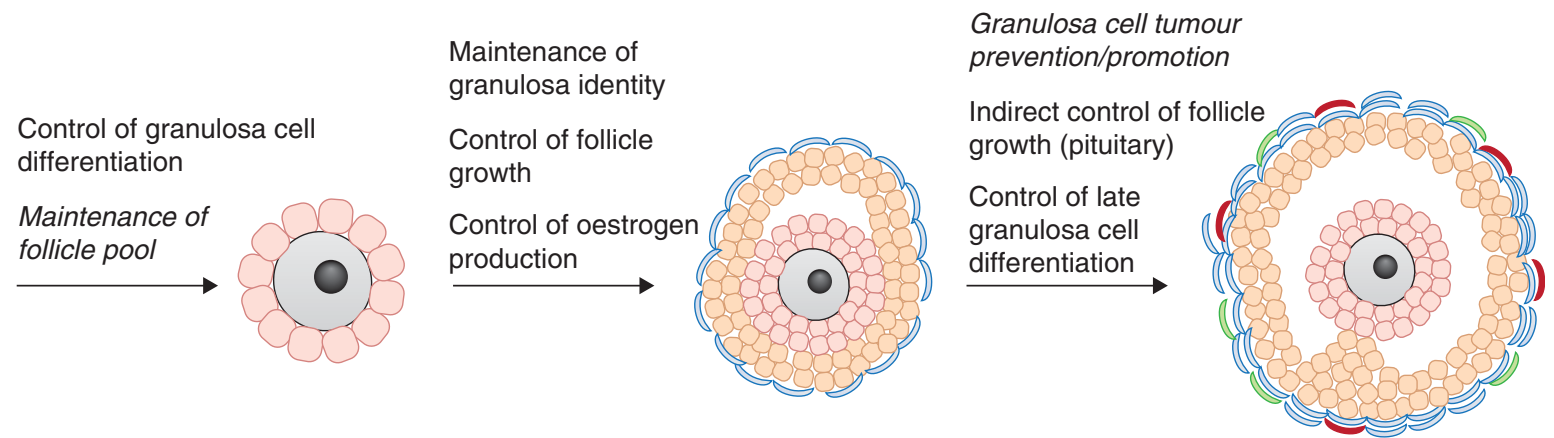

Figure 4

Overview of FOXL2 roles during folliculogenesis. Bold letters represent the physiological roles asserted from observations on mouse models or human pathologies (italicized). Normal letters correspond to potential roles suggested by in vitro studies.

pro-apoptotic factor DEADbox helicase DDX20. Interestingly, co-overexpression of DDX20 and FOXL2 in GCs leads to a decreased cell viability, but the targets potentially co-regulated by these factors are yet to be identified (Lee et al. 2005a). FOXL2 also directly interacts with several nuclear receptors important for ovarian development and function. This is the case for ESR1 and ESR2, the orphan nuclear receptor NR5A1 and its paralog NR5A2, the retinoic-acid-sensitive receptor NR2C1 and the progesterone receptor PGR (Kim et al. 2009, Uhlenhaut et al. 2009, Park et al. 2010, Ghochani et al. 2012, L'Hôte et al. 2012). Other forkhead TFs such as FOXO1 and FOXO3 can interact with a variety of nuclear receptors, suggesting a conserved interaction between these two families (van der Vos \& Coffer 2008). We have recently reported an interaction of FOXL2 with a coregulator of nuclear receptors (GMEB1) as well as with the TF CREM, involved in cAMP response. Finally, FOXL2 also interacts with chromatin regulators, such as BANF1, the DNA-repair protein XRCC6 and the histone-deacetylase SIRT1, suggesting that FOXL2 could indeed play a role in chromatin organisation (L'Hôte et al. 2012). Although an increasing number of FOXL2-interacting partners are known, the precise role of these interactions have been poorly characterised thus far. These interactions have indeed mostly been observed under conditions of overexpression and in non-physiological contexts. Future works clarifying the nature and function of the complexes involving FOXL2 in vivo would therefore be greatly informative.

\section{Future directions}

Available data show that FOXL2 performs multiple roles throughout folliculogenesis (Fig. 4). Its expression and activity seem to be finely regulated through several mechanisms and its mutation/dysregulation can be responsible for ovarian pathologies, including cancer. FOXL2 interacts with effectors and modulators of various signaling pathways, and it is therefore interesting to characterise the effect of these pathways on FOXL2 activity and target recognition. Further studies of the influence of FOXL2 on multiple signaling pathways mobilised in GCs (and vice versa) may therefore be of great interest.

The central role of FOXL2 in GC differentiation is not an isolated case within the forkhead family. Other paralogs such as FOXA1, FOXA2, FOXI1, FOXP3 and FOXG1 are also required for the determination of specific cell lineages (Lee et al. 2005b, El-Dahr et al. 2008, Danesin \& Houart 2012, Ohkura et al. 2013). It has been proposed that FOXA1 and FOXA2 play the role of pioneer TFs, which are able to remodel chromatin in a lineage-specific way. These factors thus define the subset of potential binding sites occupied by other TFs in differentiated cells, and in particular those of ubiquitous effectors such as SMADs, STATs or oestrogen receptors (Zaret \& Carroll 2011). The central position of FOXL2 in determining and maintaining GC identity suggests that it might also be a pioneer factor. Thus, it would be interesting to determine whether FOXL2 is implicated in chromatin remodeling, as suggested by its interaction with some chromatin remodeling factors. Finally, lineage-determining TFs do not act alone but in cooperation within complex regulatory networks. The determination of key signaling pathways and partners regulating or interacting with FOXL2, along with a better definition of its direct transcriptional targets, could therefore allow a better understanding of the role of FOXL2 in the ovary.

A recurrent issue in FOXL2 studies is the lack of a suitable cell model. Primary GCs from mice or rats may

Published by Bioscientifica Ltd. 
constitute a good model, but they tend to transdifferentiate in vitro, making their use rather complex and impractical for many experiments. Cultured cells from human GCTs are the most commonly used models, but they either express a mutant form of FOXL2 (KGN cell line) or do not express it at all (COV434 cell line), therefore being rather unrealistic as models of healthy GC. Recent studies have managed to derive apparently functional GCs from human and mouse embryonic stem cells (Lan et al. 2013, Woods et al. 2013). Such models could allow a better understanding of FOXL2 function in follicle function and tumorigenesis in the future.

\section{Declaration of interest}

The authors declare that there is no conflict of interest that could be perceived as prejudicing the impartiality of the review.

\section{Funding}

This work was supported by the Centre National de la Recherche Scientifique, La Ligue Nationale contre le Cancer (Comité de Paris), Université Paris Diderot-Paris7, Institut Universitaire de France and l'Agence Nationale de la Recherche (ANR)

\section{Author contribution statement}

A Auguste, L Bessière and A Vanet contributed equally to this work and are listed alphabetically.

\section{Acknowledgements}

We thank two anonymous referees for helpful comments on the manuscript.

\section{References}

Adhikari D \& Liu K 2009 Molecular mechanisms underlying the activation of mammalian primordial follicles. Endocrine Reviews 30 438-464. (doi:10.1210/er.2008-0048)

Andreu-Vieyra C, Chen R \& Matzuk MM 2008 Conditional deletion of the retinoblastoma $(R b)$ gene in ovarian granulosa cells leads to premature ovarian failure. Molecular Endocrinology 22 2141-2161. (doi:10.1210/ me.2008-0033)

Auguste A, Chassot A-A, Grégoire EP, Renault L, Pannetier M, Treier M, Pailhoux E \& Chaboissier M-C 2011 Loss of R-spondin1 and Foxl2 amplifies female-to-male sex reversal in XX mice. Sexual Development 5 304-317. (doi:10.1159/000334517)

Baarends WM, Uilenbroek JT, Kramer P, Hoogerbrugge JW, van Leeuwen EC, Themmen AP \& Grootegoed JA 1995 Anti-Müllerian hormone and antiMüllerian hormone type II receptor messenger ribonucleic acid expression in rat ovaries during postnatal development, the estrous cycle, and gonadotropin-induced follicle growth. Endocrinology 136 4951-4962. (doi:10.1210/en.136.11.4951)

Barrionuevo F, Bagheri-Fam S, Klattig J, Kist R, Taketo MM, Englert C \& Scherer G 2006 Homozygous inactivation of Sox9 causes complete XY sex reversal in mice. Biology of Reproduction 74 195-201. (doi:10.1095/ biolreprod.105.045930)

Batista F, Vaiman D, Dausset J, Fellous M \& Veitia RA 2007 Potential targets of FOXL2, a transcription factor involved in craniofacial and follicular development, identified by transcriptomics. PNAS 104 3330-3335. (doi:10.1073/pnas.0611326104)

Beamer WG, Hoppe PC \& Whitten WK 1985 Spontaneous malignant granulosa cell tumors in ovaries of young SWR mice. Cancer Research 45 $5575-5581$.

Benayoun BA, Batista F, Auer J, Dipietromaria A, L'Hôte D, De Baere E \& Veitia RA 2009 Positive and negative feedback regulates the transcription factor FOXL2 in response to cell stress: evidence for a regulatory imbalance induced by disease-causing mutations. Human Molecular Genetics 18 632-644. (doi:10.1093/hmg/ddn389)

Benayoun BA, Caburet S, Dipietromaria A, Georges A, D'Haene B, Pandaranayaka PJE, L'Hôte D, Todeschini A-L, Krishnaswamy S, Fellous M et al. 2010 Functional exploration of the adult ovarian granulosa cell tumor-associated somatic FOXL2 mutation p.Cys134Trp (c. $402 \mathrm{C}>\mathrm{G}$ ). PLOS ONE 5 e8789. (doi:10.1371/journal.pone.0008789)

Benayoun BA, Anttonen M, L'Hôte D, Bailly-Bechet M, Andersson N, Heikinheimo M \& Veitia RA 2013 Adult ovarian granulosa cell tumor transcriptomics: prevalence of FOXL2 target genes misregulation gives insights into the pathogenic mechanism of the p.Cys134Trp somatic mutation. Oncogene 32 2739-2746. (doi:10.1038/onc.2012.298)

Bentsi-Barnes IK, Kuo F-T, Barlow GM \& Pisarska MD 2010 Human forkhead L2 represses key genes in granulosa cell differentiation including aromatase, P450scc, and cyclin D2. Fertility and Sterility 94 353-356. (doi:10.1016/j.fertnstert.2009.09.050)

Bernard P, Sim H, Knower K, Vilain E \& Harley V 2008 Human SRY inhibits $\beta$-catenin-mediated transcription. International Journal of Biochemistry \& Cell Biology 40 2889-2900. (doi:10.1016/j.biocel.2008.06.006)

Blount AL, Schmidt K, Justice NJ, Vale WW, Fischer WH \& Bilezikjian LM 2009 FoxL2 and Smad3 coordinately regulate follistatin gene transcription. Journal of Biological Chemistry 284 7631-7645. (doi:10.1074/jbc.M806676200)

Boerboom D, Paquet M, Hsieh M, Liu J, Jamin SP, Behringer RR, Sirois J, Taketo MM \& Richards JS 2005 Misregulated Wnt/B-catenin signaling leads to ovarian granulosa cell tumor development. Cancer Research 65 9206-9215. (doi:10.1158/0008-5472.CAN-05-1024)

Boulanger L, Kocer A, Daniel N, Pannetier M, Chesné P, Heyman Y, Renault L, Mandon-Pépin B, Chavatte-Palmer P, Vignon X et al. 2008 Attempt to rescue sex-reversal by transgenic expression of the PISRT1 gene in XX PIS $^{-1-}$ goats. Sexual Development 2 142-151. (doi:10.1159/000143432)

Burns KH, Agno JE, Chen L, Haupt B, Ogbonna SC, Korach KS \& Matzuk MM 2003 Sexually dimorphic roles of steroid hormone receptor signaling in gonadal tumorigenesis. Molecular Endocrinology 17 2039-2052. (doi:10.1210/me.2003-0039)

Caburet S, Georges A, L'Hôte D, Todeschini A-L, Benayoun BA \& Veitia RA 2012 The transcription factor FOXL2: at the crossroads of ovarian physiology and pathology. Molecular and Cellular Endocrinology 356 55-64. (doi:10.1016/j.mce.2011.06.019)

Carlsson IB, Scott JE, Visser JA, Ritvos O, Themmen APN \& Hovatta O 2006 Anti-Müllerian hormone inhibits initiation of growth of human primordial ovarian follicles in vitro. Human Reproduction 21 2223-2227. (doi:10.1093/humrep/del165)

Chaboissier M-C, Kobayashi A, Vidal VIP, Lützkendorf S, van de Kant HJG, Wegner M, de Rooij DG, Behringer RR \& Schedl A 2004 Functiona analysis of Sox 8 and Sox 9 during sex determination in the mouse. Development 131 1891-1901. (doi:10.1242/dev.01087)

Chassot A-A, Ranc F, Gregoire EP, Roepers-Gajadien HL, Taketo MM Camerino G, de Rooij DG, Schedl A \& Chaboissier M-C 2008 Activation of $\beta$-catenin signaling by Rspo1 controls differentiation of the mammalian ovary. Human Molecular Genetics 17 1264-1277. (doi:10.1093/hmg/ddn016)

Cheng J-C, Klausen C \& Leung PCK 2013 Overexpression of wild-type but not C134W mutant FOXL2 enhances GnRH-induced cell apoptosis by 
increasing GnRH receptor expression in human granulosa cell tumors. PLOS ONE 8 e55099. (doi:10.1371/journal.pone.0055099)

Choi Y, Ballow DJ, Xin Y \& Rajkovic A $2008 a$ Lim homeobox gene, $L h x 8$, is essential for mouse oocyte differentiation and survival. Biology of Reproduction 79 442-449. (doi:10.1095/biolreprod.108.069393)

Choi Y, Yuan D \& Rajkovic A $2008 b$ Germ cell-specific transcriptional regulator Sohlh2 is essential for early mouse folliculogenesis and oocytespecific gene expression. Biology of Reproduction 79 1176-1182. (doi:10.1095/biolreprod.108.071217)

Cocquet J, Pailhoux E, Jaubert F, Servel N, Xia X, Pannetier M, Baere ED, Messiaen L, Cotinot C, Fellous M et al. 2002 Evolution and expression of FOXL2. Journal of Medical Genetics 39 916-921. (doi:10.1136/jmg.39. 12.916)

Cocquet J, Baere ED, Gareil M, Pannetier M, Xia X, Fellous M \& Veitia RA 2003 Structure, evolution and expression of the FOXL2 transcription unit. Cytogenetic and Genome Research 101 206-211. (doi:10.1159/ 000074338)

Combes AN, Spiller CM, Harley VR, Sinclair AH, Dunwoodie SL, Wilhelm D \& Koopman P 2010 Gonadal defects in Cited2-mutant mice indicate a role for SF1 in both testis and ovary differentiation. International Journal of Developmental Biology 54 683-689. (doi:10.1387/ijdb. 092920ac)

Corpuz PS, Lindaman LL, Mellon PL \& Coss D 2010 FoxL2 is required for activin induction of the mouse and human follicle-stimulating hormone $\beta$-subunit genes. Molecular Endocrinology 24 1037-1051. (doi:10.1210/me.2009-0425)

Crisponi L, Deiana M, Loi A, Chiappe F, Uda M, Amati P, Bisceglia L, Zelante L, Nagaraja R, Porcu S et al. 2001 The putative forkhead transcription factor FOXL2 is mutated in blepharophimosis/ptosis/ epicanthus inversus syndrome. Nature Genetics 27 159-166. (doi:10.1038/84781)

Dai A, Sun H, Fang T, Zhang Q, Wu S, Jiang Y, Ding L, Yan G \& Hu Y 2013 MicroRNA-133b stimulates ovarian estradiol synthesis by targeting Foxl2. FEBS Letters 587 2474-2482. (doi:10.1016/j.febslet.2013.06.023)

Danesin C \& Houart C 2012 A Fox stops the Wnt: implications for forebrain development and diseases. Current Opinion in Genetics \& Development 22 323-330. (doi:10.1016/j.gde.2012.05.001)

De Santa Barbara P, Méjean C, Moniot B, Malclès MH, Berta P \& BoizetBonhoure B 2001 Steroidogenic factor-1 contributes to the cyclic-adenosine monophosphate down-regulation of human $S R Y$ gene expression. Biology of Reproduction 64 775-783. (doi:10.1095/biolreprod64.3.775)

De Vos M, Devroey P \& Fauser BC 2011 Primary ovarian insufficiency. Lancet 376 911-921. (doi:10.1016/S0140-6736(10)60355-8)

Dipietromaria A, Benayoun BA, Todeschini A-L, Rivals I, Bazin C \& Veitia RA 2009 Towards a functional classification of pathogenic FOXL2 mutations using transactivation reporter systems. Human Molecular Genetics 18 3324-3333. (doi:10.1093/hmg/ddp273)

Dupont S, Krust A, Gansmuller A, Dierich A, Chambon P \& Mark M 2000 Effect of single and compound knockouts of estrogen receptors $\alpha(\mathrm{ER} \alpha)$ and $\beta$ (ER $\beta$ ) on mouse reproductive phenotypes. Development 127 $4277-4291$.

Durlinger ALL, Kramer P, Karels B, de Jong FH, Uilenbroek JTJ, Grootegoed JA \& Themmen APN 1999 Control of primordial follicle recruitment by anti-Müllerian hormone in the mouse ovary. Endocrinology 140 5789-5796. (doi:10.1210/en.140.12.5789)

Edson MA, Nagaraja AK \& Matzuk MM 2009 The mammalian ovary from genesis to revelation. Endocrine Reviews 30 624-712. (doi:10.1210/ er.2009-0012)

Edson MA, Nalam RL, Clementi C, Franco HL, Demayo FJ, Lyons KM, Pangas SA \& Matzuk MM 2010 Granulosa cell-expressed BMPR1A and BMPR1B have unique functions in regulating fertility but act redundantly to suppress ovarian tumor development. Molecular Endocrinology 24 1251-1266. (doi:10.1210/me. 2009-0461)
El-Dahr SS, Aboudehen K \& Saifudeen Z 2008 Transcriptional control of terminal nephron differentiation. American Journal of Physiology. Renal Physiology 294 F1273-F1278. (doi:10.1152/ajprenal.00562.2007)

Ellsworth BS, Burns AT, Escudero KW, Duval DL, Nelson SE \& Clay CM 2003 The gonadotropin releasing hormone (GnRH) receptor activating sequence (GRAS) is a composite regulatory element that interacts with multiple classes of transcription factors including Smads, AP-1 and a forkhead DNA binding protein. Molecular and Cellular Endocrinology 206 93-111. (doi:10.1016/S0303-7207(03)00235-1)

Escudero JM, Haller JL, Clay CM \& Escudero KW 2010 Microarray analysis of Foxl2 mediated gene regulation in the mouse ovary derived KK1 granulosa cell line: over-expression of Foxl2 leads to activation of the gonadotropin releasing hormone receptor gene promoter. Journal of Ovarian Research 3 4. (doi:10.1186/1757-2215-3-4)

Fisher CR, Graves KH, Parlow AF \& Simpson ER 1998 Characterization of mice deficient in aromatase (ArKO) because of targeted disruption of the cyp19 gene. PNAS 95 6965-6970. (doi:10.1073/pnas.95.12.6965)

Fleming NI, Knower KC, Lazarus KA, Fuller PJ, Simpson ER \& Clyne CD 2010 Aromatase is a direct target of FOXL2: C134W in granulosa cell tumors via a single highly conserved binding site in the ovarian specific promoter. PLoS ONE 5 e14389. (doi:10.1371/journal.pone.0014389)

Garcia-Ortiz JE, Pelosi E, Omari S, Nedorezov T, Piao Y, Karmazin J, Uda M, Cao A, Cole SW, Forabosco A et al. 2009 Foxl2 functions in sex determination and histogenesis throughout mouse ovary development. BMC Developmental Biology 9 36. (doi:10.1186/1471-213X-9-36)

Georges A, Benayoun BA, Marongiu M, Dipietromaria A, L'Hôte D, Todeschini A-L, Auer J, Crisponi L \& Veitia RA 2011 SUMOylation of the forkhead transcription factor FOXL2 promotes its stabilization/ activation through transient recruitment to PML bodies. PLoS ONE 6 e25463. (doi:10.1371/journal.pone.0025463)

Ghochani Y, Saini JK, Mellon PL \& Thackray VG 2012 FOXL2 is involved in the synergy between activin and progestins on the follicle-stimulating hormone $\beta$-subunit promoter. Endocrinology 153 2023-2033. (doi:10. 1210/en.2011-1763)

Hiramatsu R, Harikae K, Tsunekawa N, Kurohmaru M, Matsuo I \& Kanai Y 2010 FGF signaling directs a center-to-pole expansion of tubulogenesis in mouse testis differentiation. Development 137 303-312. (doi:10. 1242/dev.040519)

Huang EJ, Manova K, Packer AI, Sanchez S, Bachvarova RF \& Besmer P 1993 The murine steel panda mutation affects Kit ligand expression and growth of early ovarian follicles. Developmental Biology 157 100-109. (doi:10.1006/dbio.1993.1115)

Jamieson S \& Fuller PJ 2012 Molecular pathogenesis of granulosa cell tumors of the ovary. Endocrine Reviews 33 109-144. (doi:10.1210/er. 2011-0014)

Jamieson S, Butzow R, Andersson N, Alexiadis M, Unkila-Kallio L, Heikinheimo M, Fuller PJ \& Anttonen M 2010 The FOXL2 C134W mutation is characteristic of adult granulosa cell tumors of the ovary. Modern Pathology 23 1477-1485. (doi:10.1038/modpathol.2010.145)

John GB, Gallardo TD, Shirley LJ \& Castrillon DH 2008 Foxo3 is a PI3K-dependent molecular switch controlling the initiation of oocyte growth. Developmental Biology 321 197-204. (doi:10.1016/ j.ydbio.2008.06.017)

Jorgez CJ, Klysik M, Jamin SP, Behringer RR \& Matzuk MM 2004 Granulosa cell-specific inactivation of follistatin causes female fertility defects. Molecular Endocrinology 18 953-967. (doi:10.1210/me.2003-0301)

Justice NJ, Blount AL, Pelosi E, Schlessinger D, Vale W \& Bilezikjian LM 2011 Impaired FSH $\beta$ expression in the pituitaries of Foxl2 mutant animals. Molecular Endocrinology 25 1404-1415. (doi:10.1210/ me.2011-0093)

Kalfa N, Philibert P, Patte C, Ecochard A, Duvillard P, Baldet P, Jaubert F, Fellous M \& Sultan C 2007 Extinction of FOXL2 expression in aggressive ovarian granulosa cell tumors in children. Fertility and Sterility 87 896-901. (doi:10.1016/j.fertnstert.2006.11.016)

Kashimada K, Pelosi E, Chen H, Schlessinger D, Wilhelm D \& Koopman P 2011 FOXL2 and BMP2 act cooperatively to regulate follistatin gene

Published by Bioscientifica Ltd. 
expression during ovarian development. Endocrinology 152 272-280. (doi:10.1210/en.2010-0636)

Kezele P, Nilsson EE \& Skinner MK 2005 Keratinocyte growth factor acts as a mesenchymal factor that promotes ovarian primordial to primary follicle transition. Biology of Reproduction 73 967-973. (doi:10.1095/ biolreprod.105.043117)

Kim S-Y, Weiss J, Tong M, Laronda MM, Lee E-J \& Jameson JL 2009 Foxl2, a forkhead transcription factor, modulates nonclassical activity of the estrogen receptor- $\alpha$. Endocrinology 150 5085-5093. (doi:10.1210/en. 2009-0313)

Kim J-H, Yoon S, Park M, Park H-O, Ko J-J, Lee K \& Bae J 2011 Differential apoptotic activities of wild-type FOXL2 and the adult-type granulosa cell tumor-associated mutant FOXL2 (C134W). Oncogene 30 1653-1663. (doi:10.1038/onc.2010.541)

Kuo F-T, Bentsi-Barnes IK, Barlow GM, Bae J \& Pisarska MD 2009 Sumoylation of forkhead L2 by Ubc9 is required for its activity as a transcriptional repressor of the steroidogenic acute regulatory gene. Cellular Signalling 21 1935-1944. (doi:10.1016/j.cellsig.2009.09.001)

Kuo F-T, Bentsi-Barnes IK, Barlow GM \& Pisarska MD 2011 Mutant forkhead L2 (FOXL2) proteins associated with premature ovarian failure (POF) dimerize with wild-type FOXL2, leading to altered regulation of genes associated with granulosa cell differentiation. Endocrinology 152 3917-3929. (doi:10.1210/en.2010-0989)

Lakhal B, Ben-Hadj-Khalifa S, Bouali N, Philipert P, Audran F, Braham R, Hatem E, Sultan C \& Saad A 2012 Mutational screening of SF1 and WNT4 in Tunisian women with premature ovarian failure. Gene $\mathbf{5 0 9}$ 298-301. (doi:10.1016/j.gene.2012.08.007)

Lamba P, Fortin J, Tran S, Wang Y \& Bernard DJ 2009 A novel role for the forkhead transcription factor FOXL2 in activin A-regulated folliclestimulating hormone $\beta$ subunit transcription. Molecular Endocrinology 23 1001-1013. (doi:10.1210/me.2008-0324)

Lamba P, Wang Y, Tran S, Ouspenskaia T, Libasci V, Hébert TE, Miller GJ \& Bernard DJ 2010 Activin A regulates porcine follicle-stimulating hormone $\beta$-subunit transcription via cooperative actions of SMADs and FOXL2. Endocrinology 151 5456-5467. (doi:10.1210/en.2010-0605)

Lan C-W, Chen M-J, Jan P-S, Chen H-F \& Ho H-N 2013 Differentiation of human embryonic stem cells into functional ovarian granulosa-like cells. Journal of Clinical Endocrinology and Metabolism 98 3713-3723. (doi:10.1210/jc.2012-4302)

Lee W-S, Otsuka F, Moore RK \& Shimasaki S 2001 Effect of bone morphogenetic protein-7 on folliculogenesis and ovulation in the rat. Biology of Reproduction 65 994-999. (doi:10.1095/biolreprod65.4.994)

Lee MB, Lebedeva LA, Suzawa M, Wadekar SA, Desclozeaux M \& Ingraham HA 2005a The DEAD-box protein DP103 (Ddx20 or Gemin-3) represses orphan nuclear receptor activity via SUMO modification. Molecular and Cellular Biology 25 1879-1890. (doi:10.1128/MCB.25.5.1879-1890.2005)

Lee CS, Friedman JR, Fulmer JT \& Kaestner KH $2005 b$ The initiation of liver development is dependent on Foxa transcription factors. Nature $\mathbf{4 3 5}$ 944-947. (doi:10.1038/nature03649)

L'Hôte D, Georges A, Todeschini AL, Kim J-H, Benayoun BA, Bae J \& Veitia RA 2012 Discovery of novel protein partners of the transcription factor FOXL2 provides insights into its physiopathological roles. Human Molecular Genetics 21 3264-3274. (doi:10.1093/hmg/dds170)

Lima JF, Jin L, de Araujo ARC, Erikson-Johnson MR, Oliveira AM, Sebo TJ, Keeney GL \& Medeiros F 2012 FOXL2 mutations in granulosa cell tumors occurring in males. Archives of Pathology \& Laboratory Medicine 136 825-828. (doi:10.5858/arpa.2011-0355-OA)

Liu C-F, Bingham N, Parker K \& Yao HH-C 2009 Sex-specific roles of $\beta$-catenin in mouse gonadal development. Human Molecular Genetics 18 405-417. (doi:10.1093/hmg/ddn362)

Liu AM, Wong K-F, Jiang X, Qiao Y \& Luk JM 2012 Regulators of mammalian Hippo pathway in cancer. Biochimica et Biophysica Acta 1826 357-364. (doi:10.1016/j.bbcan.2012.05.006)

Maatouk DM, DiNapoli L, Alvers A, Parker KL, Taketo MM \& Capel B 2008 Stabilization of $\beta$-catenin in XY gonads causes male-to-female sex-reversal. Human Molecular Genetics 17 2949-2955. (doi:10.1093/ hmg/ddn193)

Manuylov NL, Smagulova FO, Leach L \& Tevosian SG 2008 Ovarian development in mice requires the GATA4-FOG2 transcription complex. Development 135 3731-3743. (doi:10.1242/dev.024653)

Marongiu M, Deiana M, Meloni A, Marcia L, Puddu A, Cao A, Schlessinger D \& Crisponi L 2010 The forkhead transcription factor Foxl2 is sumoylated in both human and mouse: sumoylation affects its stability, localization, and activity. PLOS ONE 5 e9477. (doi:10.1371/journal.pone.0009477)

Matson CK, Murphy MW, Sarver AL, Griswold MD, Bardwell VJ \& Zarkower D 2011 DMRT1 prevents female reprogramming in the postnatal mammalian testis. Nature 476 101-104. (doi:10.1038/ nature10239)

Matzuk MM, Finegold MJ, Su JG, Hsueh AJ \& Bradley A $1992 \alpha$-Inhibin is a tumour-suppressor gene with gonadal specificity in mice. Nature $\mathbf{3 6 0}$ 313-319. (doi:10.1038/360313a0)

McCue PM, Roser JF, Munro CJ, Liu IKM \& Lasley BL 2006 Granulosa cell tumors of the equine ovary. Veterinary Clinics of North America. Equine Practice 22 799-817. (doi:10.1016/j.cveq.2006.08.008)

McTavish KJ, Nonis D, Hoang YD \& Shimasaki S 2013 Granulosa cell tumor mutant FOXL2 ${ }^{\mathrm{C} 134 \mathrm{~W}}$ suppresses GDF-9 and activin A-induced follistatin transcription in primary granulosa cells. Molecular and Cellular Endocrinology 372 57-64. (doi:10.1016/j.mce.2013.03.021)

Miyamoto Y, Taniguchi H, Hamel F, Silversides DW \& Viger RS 2008 A GATA4/WT1 cooperation regulates transcription of genes required for mammalian sex determination and differentiation. BMC Molecular Biology 9 44. (doi:10.1186/1471-2199-9-44)

Moumné L, Dipietromaria A, Batista F, Kocer A, Fellous M, Pailhoux E \& Veitia RA 2008 Differential aggregation and functional impairment induced by polyalanine expansions in FOXL2, a transcription factor involved in cranio-facial and ovarian development. Human Molecular Genetics 17 1010-1019. (doi:10.1093/hmg/ddm373)

Nilsson EE \& Skinner MK 2003 Bone morphogenetic protein-4 acts as an ovarian follicle survival factor and promotes primordial follicle development. Biology of Reproduction 69 1265-1272. (doi:10.1095/ biolreprod.103.018671)

Nilsson EE \& Skinner MK 2004 Kit ligand and basic fibroblast growth factor interactions in the induction of ovarian primordial to primary follicle transition. Molecular and Cellular Endocrinology 214 19-25. (doi:10. 1016/j.mce.2003.12.001)

Nilsson EE, Kezele P \& Skinner MK 2002 Leukemia inhibitory factor (LIF) promotes the primordial to primary follicle transition in rat ovaries. Molecular and Cellular Endocrinology 188 65-73. (doi:10.1016/S03037207(01)00746-8)

Nilsson E, Rogers N \& Skinner MK 2007 Actions of anti-Müllerian hormone on the ovarian transcriptome to inhibit primordial to primary follicle transition. Reproduction 134 209-221. (doi:10.1530/ REP-07-0119)

Nonis D, McTavish KJ \& Shimasaki S 2013 Essential but differential role of FOXL2 ${ }^{\mathrm{wt}}$ and FOXL2 ${ }^{\mathrm{C} 134 \mathrm{~W}}$ in GDF-9 stimulation of follistatin transcription in co-operation with Smad3 in the human granulosa cell line COV434. Molecular and Cellular Endocrinology 372 42-48. (doi:10.1016/ j.mce.2013.02.020)

Ohishi Y, Oda Y, Kurihara S, Kaku T, Kobayashi H, Wake N \& Tsuneyoshi M 2011 Nuclear localization of E-cadherin but not $\beta$-catenin in human ovarian granulosa cell tumours and normal ovarian follicles and ovarian stroma. Histopathology 58 423-432. (doi:10.1111/j.1365-2559. 2011.03761.x)

Ohkura N, Kitagawa Y \& Sakaguchi S 2013 Development and maintenance of regulatory T cells. Immunity 38 414-423. (doi:10.1016/j.immuni. 2013.03.002)

Pailhoux E, Vigier B, Schibler L, Cribiu EP, Cotinot C \& Vaiman D 2005 Positional cloning of the PIS mutation in goats and its impact on understanding mammalian sex-differentiation. Genetics, Selection, Evolution 37 (Suppl 1) S55-S64. (doi:10.1186/1297-9686-37-S1-S55) 
Pangas SA, Choi Y, Ballow DJ, Zhao Y, Westphal H, Matzuk MM \& Rajkovic A 2006 Oogenesis requires germ cell-specific transcriptional regulators Sohlh1 and Lhx8. PNAS 103 8090-8095. (doi:10.1073/pnas. 0601083103)

Pangas SA, Li X, Umans L, Zwijsen A, Huylebroeck D, Gutierrez C, Wang D, Martin JF, Jamin SP, Behringer RR et al. 2008 Conditional deletion of Smad1 and Smad5 in somatic cells of male and female gonads leads to metastatic tumor development in mice. Molecular and Cellular Biology 28 248-257. (doi:10.1128/MCB.01404-07)

Pannetier M, Fabre S, Batista F, Kocer A, Renault L, Jolivet G, Mandon-Pepin B, Cotinot C, Veitia R \& Pailhoux E 2006 FOXL2 activates P450 aromatase gene transcription: towards a better characterization of the early steps of mammalian ovarian development. Journal of Molecular Endocrinology 36 399-413. (doi:10.1677/jme.1.01947)

Paredes A, Romero C, Dissen GA, DeChiara TM, Reichardt L, Cornea A, Ojeda SR \& Xu B 2004 TrkB receptors are required for follicular growth and oocyte survival in the mammalian ovary. Developmental Biology 267 430-449. (doi:10.1016/j.ydbio.2003.12.001)

Park M, Shin E, Won M, Kim J-H, Go H, Kim H-L, Ko J-J, Lee K \& Bae J 2010 FOXL2 interacts with steroidogenic factor-1 (SF-1) and represses SF-1induced CYP17 transcription in granulosa cells. Molecular Endocrinology 24 1024-1036. (doi:10.1210/me.2009-0375)

Parrott JA \& Skinner MK 1999 Kit-ligand/stem cell factor induces primordial follicle development and initiates folliculogenesis. Endocrinology 140 4262-4271. (doi:10.1210/en.140.9.4262)

Pisarska MD, Bae J, Klein C \& Hsueh AJW 2004 Forkhead 12 is expressed in the ovary and represses the promoter activity of the steroidogenic acute regulatory gene. Endocrinology 145 3424-3433. (doi:10.1210/ en.2003-1141)

Pisarska MD, Kuo F-T, Bentsi-Barnes IK, Khan S \& Barlow GM 2010 LATS1 phosphorylates forkhead L2 and regulates its transcriptional activity. American Journal of Physiology. Endocrinology and Metabolism 299 E101-E109. (doi:10.1152/ajpendo.00534.2009)

Pisarska MD, Barlow G \& Kuo F-T 2011 Minireview: roles of the forkhead transcription factor FOXL2 in granulosa cell biology and pathology. Endocrinology 152 1199-1208. (doi:10.1210/en.2010-1041)

Poznic M 2009 Retinoblastoma protein: a central processing unit. Journal of Biosciences 34 305-312. (doi:10.1007/s12038-009-0034-2)

Qin Y, Choi Y, Zhao H, Simpson JL, Chen Z-J \& Rajkovic A 2007 NOBOX homeobox mutation causes premature ovarian failure. American Journal of Human Genetics 81 576-581. (doi:10.1086/519496)

Rajareddy S, Reddy P, Du C, Liu L, Jagarlamudi K, Tang W, Shen Y, Berthet C, Peng SL, Kaldis P et al. 2007 p2 $7^{\text {kip1 }}$ (cyclin-dependent kinase inhibitor 1B) controls ovarian development by suppressing follicle endowment and activation and promoting follicle atresia in mice. Molecular Endocrinology 21 2189-2202. (doi:10.1210/me.2007-0172)

Rajkovic A, Pangas SA, Ballow D, Suzumori N \& Matzuk MM 2004 NOBOX deficiency disrupts early folliculogenesis and oocyte-specific gene expression. Science 305 1157-1159. (doi:10.1126/science.1099755)

Reddy P, Shen L, Ren C, Boman K, Lundin E, Ottander U, Lindgren P, Liu Y-X, Sun Q-Y \& Liu K 2005 Activation of Akt (PKB) and suppression of FKHRL1 in mouse and rat oocytes by stem cell factor during follicular activation and development. Developmental Biology 281 160-170. (doi:10.1016/j.ydbio.2005.02.013)

Reddy P, Liu L, Adhikari D, Jagarlamudi K, Rajareddy S, Shen Y, Du C, Tang W, Hämäläinen T, Peng SL et al. 2008 Oocyte-specific deletion of Pten causes premature activation of the primordial follicle pool. Science $\mathbf{3 1 9}$ 611-613. (doi:10.1126/science.1152257)

Richards JS, Fan H-Y, Liu Z, Tsoi M, Laguë M-N, Boyer A \& Boerboom D 2012 Either Kras activation or Pten loss similarly enhance the dominant-stable CTNNB1-induced genetic program to promote granulosa cell tumor development in the ovary and testis. Oncogene $\mathbf{3 1}$ 1504-1520. (doi:10.1038/onc.2011.341)

Risma KA, Clay CM, Nett TM, Wagner T, Yun J \& Nilson JH 1995 Targeted overexpression of luteinizing hormone in transgenic mice leads to infertility, polycystic ovaries, and ovarian tumors. PNAS 92 1322-1326. (doi:10.1073/pnas.92.5.1322)

Rosario R, Araki H, Print CG \& Shelling AN 2012 The transcriptional targets of mutant FOXL2 in granulosa cell tumours. PLOS ONE 7 e46270. (doi:10.1371/journal.pone.0046270)

Rosario R, Blenkiron C \& Shelling AN 2013 Comparative study of microRNA regulation on FOXL2 between adult-type and juvenile-type granulosa cell tumours in vitro. Gynecologic Oncology 129 209-215. (doi:10.1016/j.ygyno.2012.12.034)

Schmidt D, Ovitt CE, Anlag K, Fehsenfeld S, Gredsted L, Treier A-C \& Treier M 2004 The murine winged-helix transcription factor Foxl2 is required for granulosa cell differentiation and ovary maintenance. Development 131 933-942. (doi:10.1242/dev.00969)

Shah SP, Köbel M, Senz J, Morin RD, Clarke BA, Wiegand KC, Leung G, Zayed A, Mehl E, Kalloger SE et al. 2009 Mutation of FOXL2 in granulosa-cell tumors of the ovary. New England Journal of Medicine $\mathbf{3 6 0}$ 2719-2729. (doi:10.1056/NEJMoa0902542)

Steinmetz R, Wagoner HA, Zeng P, Hammond JR, Hannon TS, Meyers JL \& Pescovitz OH 2004 Mechanisms regulating the constitutive activation of the extracellular signal-regulated kinase (ERK) signaling pathway in ovarian cancer and the effect of ribonucleic acid interference for ERK1/2 on cancer cell proliferation. Molecular Endocrinology 18 2570-2582. (doi:10.1210/me.2004-0082)

St John MA, Tao W, Fei X, Fukumoto R, Carcangiu ML, Brownstein DG, Parlow AF, McGrath J \& Xu T 1999 Mice deficient of Lats1 develop soft-tissue sarcomas, ovarian tumours and pituitary dysfunction. Nature Genetics 21 182-186. (doi:10.1038/5965)

Tavassoli FA \& Devilee P (Eds) 2003 World Health Organization Classification of Tumours. Pathology and Genetics of Tumours of the Breast and Female Genital Organs. Lyon: IARC Press.

Todeschini A-L, Dipietromaria A, L'Hôte D, Boucham FZ, Georges AB, Pandaranayaka PJE, Krishnaswamy S, Rivals I, Bazin C \& Veitia RA 2011 Mutational probing of the forkhead domain of the transcription factor FOXL2 provides insights into the pathogenicity of naturally occurring mutations. Human Molecular Genetics 20 3376-3385. (doi:10.1093/ $\mathrm{hmg} / \mathrm{ddr} 244)$

Tran S, Lamba P, Wang Y \& Bernard DJ 2011 SMADs and FOXL2 synergistically regulate murine FSH $\beta$ transcription via a conserved proximal promoter element. Molecular Endocrinology 25 1170-1183. (doi:10.1210/me.2010-0480)

Tran S, Zhou X, Lafleur C, Calderon MJ, Ellsworth BS, Kimmins S, Boehm U, Treier M, Boerboom D \& Bernard DJ 2013 Impaired fertility and FSH synthesis in gonadotrope-specific Foxl2 knockout mice. Molecular Endocrinology 27 407-421. (doi:10.1210/me.2012-1286)

Uda M, Ottolenghi C, Crisponi L, Garcia JE, Deiana M, Kimber W, Forabosco A, Cao A, Schlessinger D \& Pilia G 2004 Foxl2 disruption causes mouse ovarian failure by pervasive blockage of follicle development. Human Molecular Genetics 13 1171-1181. (doi:10.1093/hmg/ddh124)

Uhlenhaut NH, Jakob S, Anlag K, Eisenberger T, Sekido R, Kress J, Treier A-C, Klugmann C, Klasen C, Holter NI et al. 2009 Somatic sex reprogramming of adult ovaries to testes by FOXL2 ablation. Cell 139 1130-1142. (doi:10.1016/j.cell.2009.11.021)

Vainio S, Heikkilä M, Kispert A, Chin N \& McMahon AP 1999 Female development in mammals is regulated by Wnt-4 signalling. Nature $\mathbf{3 9 7}$ 405-409. (doi:10.1038/17068)

Van der Vos KE \& Coffer PJ 2008 FOXO-binding partners: it takes two to tango. Oncogene 27 2289-2299. (doi:10.1038/onc.2008.22)

Verdin H \& De Baere E 2012 FOXL2 impairment in human disease. Hormone Research in Paediatrics 77 2-11. (doi:10.1159/000335236)

Vidal VP, Chaboissier MC, de Rooij DG \& Schedl A 2001 Sox9 induces testis development in XX transgenic mice. Nature Genetics 28 216-217. (doi:10.1038/90046)

Watson RH, Roy WJ Jr, Davis M, Hitchcock A \& Campbell IG 1997 Loss of heterozygosity at the $\alpha$-inhibin locus on chromosome $2 \mathrm{q}$ is not a feature of human granulosa cell tumors. Gynecologic Oncology 65 387-390. (doi:10.1006/gyno.1997.4682) 
Woods DC, White YAR, Niikura Y, Kiatpongsan S, Lee H-J \& Tilly JL 2013 Embryonic stem cell-derived granulosa cells participate in ovarian follicle formation in vitro and in vivo. Reproductive Sciences 20 524-535. (doi:10.1177/1933719113483017)

Yao HH-C, Whoriskey W \& Capel B 2002 Desert Hedgehog/Patched 1 signaling specifies fetal Leydig cell fate in testis organogenesis. Genes and Development 16 1433-1440. (doi:10.1101/gad.981202)

Yao HHC, Matzuk MM, Jorgez CJ, Menke DB, Page DC, Swain A \& Capel B 2004 Follistatin operates downstream of Wnt4 in mammalian ovary organogenesis. Developmental Dynamics 230 210-215. (doi:10.1002/ dvdy.20042)

Yoshida H, Takakura N, Kataoka H, Kunisada T, Okamura H \& Nishikawa SI 1997 Stepwise requirement of c-kit tyrosine kinase in mouse ovarian follicle development. Developmental Biology 184 122-137. (doi:10.1006/ dbio.1997.8503)

Zaret KS \& Carroll JS 2011 Pioneer transcription factors: establishing competence for gene expression. Genes and Development 25 2227-2241. (doi:10.1101/gad.176826.111)

Received in final form 26 August 2013

Accepted 18 September 2013

Accepted Preprint published online 18 September 2013
Published by Bioscientifica Ltd. 